\title{
ARTICLE
}

\section{Copper complexes for the promotion of iminopyridine ligands derived from $\beta$-alanine and self-aldol additions: Relaxivity and cytotoxic properties}

Received 00th January 20xx Accepted 00th January 20xx DOI: $10.1039 / x 0 x \times 00000 x$

\begin{abstract}
Lucía Álvarez-Miguel, a Inés Álvarez-Miguel, ${ }^{\text {b }}$ José M. Martín-Álvarez, ${ }^{a}$ Celedonio M. Álvarez, ${ }^{a}$ Guillaume Rogez, ${ }^{c}$ Raúl García-Rodríguez ${ }^{\mathrm{a}} *$ and Daniel Miguel ${ }^{\mathrm{a}} *$

In the study presented herein, we explore the ability of copper complexes with coordinated pyridine-2-carboxaldehyde (pyca) or 2-acetylpyridine (acepy) ligands to promote the addition of amines (Schiff condensation) and other nucleophiles such as alcohols (hemiacetal formation). Distinct reactivity patterns are observed: unlike pyca complexes, acepy copper complexes can promote self-aldol addition. The introduction of a flexible chain via Schiff condensation with $\beta$-alanine allows the possibility of chelate ring ring-opening processes mediated by $\mathrm{pH}$. Further derivatization of the complex [CuCl(py-2- $\left.\left.\mathrm{C}(\mathrm{H})=\mathrm{NCH}_{2} \mathrm{CH}_{2} \mathrm{COO}\right)\right]$ is possible by replacing its chloride ligand with different pseudohalogens $\left(\mathrm{N}_{3}{ }^{-}, \mathrm{NCO}^{-}\right.$and NCS). In addition to the change in their magnetism, which correlates with their solid-state structures, more unexpected effects in their cytotoxicity and relaxitivities are observed, which determines their possibility to be used as MRI contrast agents. The replacement of a chloride by another pseudohalogen, although a simple strategy, can be used to critically change the cytotoxicity of the Schiff base copper(II) complex and its selectivity towards specific cell lines.
\end{abstract}

\section{Introduction}

Copper is a bioessential element for humans, and a wide variety of $\mathrm{Cu}$ complexes have been demonstrated to be excellent potential candidates for biological and medical applications. ${ }^{1-8}$ Among the plethora of $\mathrm{Cu}$ (II) compounds that have been tested as anticancer agents, complexes with Schiff base ligands have emerged as promising candidates. ${ }^{9-13}$ Since the pioneering work of Reedijk et al. ${ }^{14,15}$ on Schiff base derivatives of pyrimol with copper and other metals, several groups have assessed the DNA cleavage, cytotoxicity and apoptosis induction activities of related families of copper complexes. ${ }^{16-18}$ Additionally, there is a current interest in the development of paramagnetic complexes to be used as relaxation agents for contrast in magnetic resonance imaging (MRI). ${ }^{19-21}$ The main focus has been complexes with many unpaired electrons, such as those of $\operatorname{Gd}(\mathrm{III})\left(\mathrm{f}^{7}\right) .{ }^{21 \mathrm{~b}-\mathrm{e}}$ However, the intrinsic toxicity of $\mathrm{Gd}^{22,23}$ and most heavy metals has driven interest in complexes of first row transition metals, ${ }^{19,24}$

\footnotetext{
a. GIR MIOMET-IU CINQUIMA/Química Inorgánica, Facultad de Ciencias, Universidad de Valladolid. Paseo de Belen 7, E-47011 Valladolid, Spain. E-mail: raul.garcia.rodriguez@uva.es,dmsj@qi.uva.es.

${ }^{b .}$ Instituto de Biología y Genética Molecular (IBGM). Universidad de Valladolid/CSIC Sanz y Fores, 3, E-47003 Valladolid Spain

Institut de Physique et Chimie des Matériaux de Strasbourg, UMR 7504 UdS-CNRS Cedex 2, 67034 Strasbourg France.

+ Electronic Supplementary Information (ESI) available: CCDC 1491835-1491841, 1955681-1955683 and 1955678. See DOI: 10.1039/x0xx00000x
}

${ }^{27}$ which are less toxic. Although these complexes exhibit lower relaxivity, they can be tailored for greater target specificity. For example, the well-known histological stain Luxol fast blue (LFB), a copper (II) phthalocyanine, has been tested as an MRI contrast agent. ${ }^{28}$ However, some of these complexes have cumbersome syntheses or involve ligands that are difficult to isolate. In particular, the synthesis of polydentate ligands can be multi-step and time-consuming. It is interesting, therefore, to develop systematic procedures for the synthesis and modification of families of complexes whose properties can be tuned by introducing different ligands and substituents.

We have been interested in complexes containing pyridine-2carboxaldehyde (pyca) as chelating $\mathrm{K}^{2}(\mathrm{~N}, \mathrm{O})$ ligands, ${ }^{29-33}$ which can serve as precursors for the introduction of metal-ligand fragments in biomolecules. ${ }^{34-36}$ In addition to this, the preparation of the ligands within the metal coordination sphere is also a simple and one-pot procedure, which avoids the need for typical multi-step, time-consuming ligand preparation and purification protocols. In this vein, we have recently found that the $\mathrm{Cu}(\mathrm{II})$ complex $1 \mathrm{a}$, in which pyca is coordinated as $\mathrm{K}^{2}(\mathrm{~N}, \mathrm{O})$ to the metal, is able to undergo aldol addition with different ketones under mild and neutral conditions due to the enhanced electrophilic character of the aldehyde upon copper coordination (Fig 1A). ${ }^{37}$ Complex 1a could not be isolated, but could be prepared in situ. We reasoned that the coordination of 2-pyridine carboxaldehyde (pyca) to copper should also enhance the reactivity towards other nucleophiles such as amines and facilitate Schiff base 
condensation (Fig 1B). Simple access to complexes of this type is important. In this regard, copper (II) complexes containing Schiff base ligands derived from $\beta$-alanine ${ }^{38,39}$ have shown different interesting properties, for example, antiradical and antidiabetic activity. ${ }^{40}$ Other Schiff base complexes derived from pyca have been used as catalysts for the oxidation of cyclohexane $^{41-43}$ and alcohols and for nitroaldol additions. ${ }^{44}$

In the study presented herein, we explore the ability of 1a and novel isolatable complexes $\mathbf{1 b}$ and $\mathbf{2} \mathbf{b}$, in which an $\mathbf{2 -}$ acetylpyridine (acepy) ligand is coordinated to $\mathrm{Cu}(\mathrm{II})$, to promote the addition of amines (Schiff condensation) and other nucleophiles such as alcohols (hemiacetal formation) in the coordination sphere of the metal. We show that acepy copper complexes, unlike pyca complexes, can promote the self-aldol addition due to the chelate coordination of the ligand to copper, which facilitates the formation of the metal enolate (Fig. 1C). We also conduct preliminary studies on the influence of simple chloride ligand substitution on the cytotoxicity and relaxivity of the prepared Schiff base $\beta$-ala copper complex.
A)

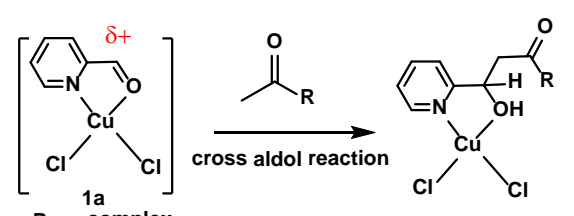

B) Pyca complex

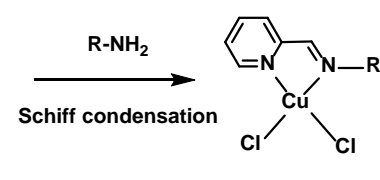

yca complex

C)

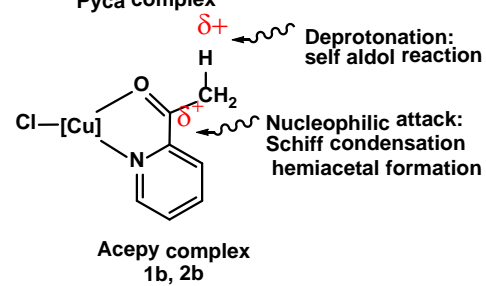

Figure 1. A) Reactivity of $1 \mathrm{a}$ in the promotion of the cross-aldol reaction. ${ }^{37} \mathrm{~B}$ ) Template formation of Schiff bases by reaction of amines (this work). C) Reactivity of acepy complexes facilitating different nucleophilic processes (this work).

\section{Results and discussion}

\section{Synthesis and structural characterization of acepy copper(II)} complexes

We have previously shown that the reaction of $\mathrm{CuCl}_{2} \cdot 2 \mathrm{H}_{2} \mathrm{O}$ with pyridine-2-carboxaldehyde (pyca) produces the coordination of the pyca ligand to give compound 1a, which could not be isolated. In contrast, the addition of an excess of pyca leads to complex $\mathbf{2 a}$, which could be isolated in high yields (Scheme 1a). ${ }^{37}$ Herein, in a similar manner, 2acetylpyridine (acepy) reacts with $\mathrm{CuCl}_{2} \cdot 2 \mathrm{H}_{2} \mathrm{O}$ in THF to afford compound $\mathbf{1 b}$ (see Scheme $\mathbf{1 b}$ ). Compound $\mathbf{1 b}$ precipitates out cleanly in THF and can be isolated in excellent yield (93\%). The solid-state structure of $\mathbf{1 b}$ reveals that acepy acts as a $\kappa^{2}(\mathrm{~N}, \mathrm{O})$ bidentate chelate ligand accompanied by two chloride ligands. A pentacoordinate-type arrangement is formed by the long contact of the $\mathrm{Cl}$ ligand of a nearby molecule, thus giving rise to a centrosymmetric dimer with concerted unsymmetrical chloride bridges, as seen in Figure 2 top.

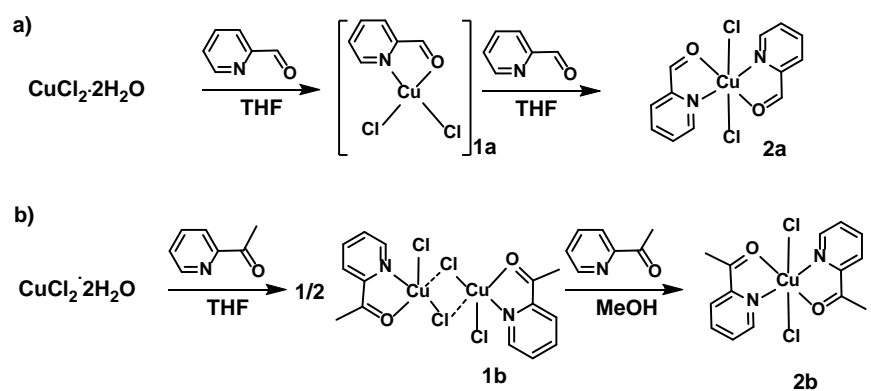

Scheme 1. a) Synthesis of copper pyca complexes $1 \mathbf{a}$ and $2 \mathbf{a}$. b) Synthesis of coper acepy complexes $\mathbf{1} \mathbf{b}$ and $\mathbf{2} \mathbf{b}$.

Compound $\mathbf{1 b}$ reacts with an additional equivalent of acepy in $\mathrm{MeOH}$ to afford complex $\mathbf{2} \mathbf{b}$ as a green precipitate. This compound can also be obtained by simply reacting $\mathrm{CuCl}_{2} \cdot 2 \mathrm{H}_{2} \mathrm{O}$ with two equivalents of acepy. In the structure of $\mathbf{2 b}$ (Figure $\mathbf{2}$, below) the copper atom is surrounded by two chloride ligands in a trans arrangement and two acepy ligands coordinated as $\kappa^{2}(\mathrm{~N}, \mathrm{O})$ bidentate chelates, thus completing a distorted octahedral six-coordinate environment for the copper atom. The $\mathrm{Cu}-\mathrm{O}$ distances are longer than expected for a normal bond (2.380(2) in $\mathbf{2 b}$, cf. 2.042(3) in 1b). The IR spectra of both complexes show a decrease in the $\mathrm{v}(\mathrm{CO})\left(1633\right.$ and $1686 \mathrm{~cm}^{-1}$, respectively for $\mathbf{1 b}$ and $\mathbf{2 b}$ ) with respect to that of free acepy ligand $\left(\mathrm{v}(\mathrm{CO}) 1697 \mathrm{~cm}^{-1}\right)$, indicating that the carbonyl group is activated for nucleophilic attack by copper coordination. This activation was found to be stronger in $\mathbf{1 b}$; therefore, this compound was selected for subsequent studies.

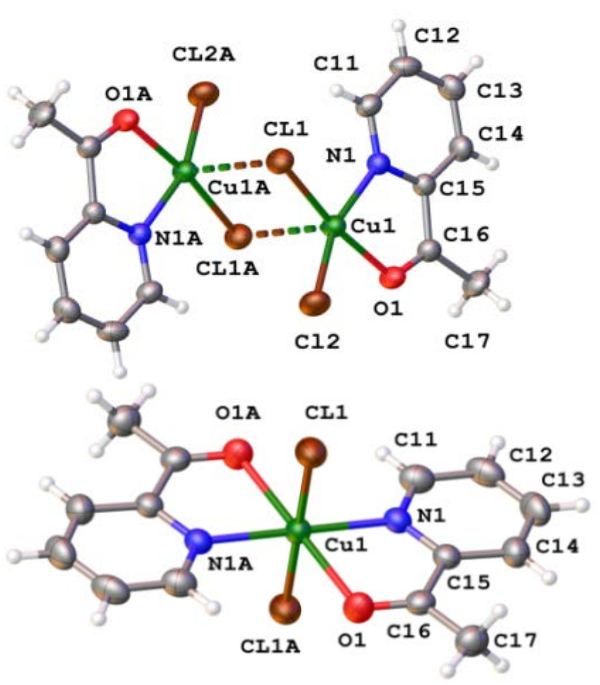

Fig. 2 (Top) Perspective view of compound $\mathbf{1 b}$ showing the atom numbering. Selected bond distances $(\AA)$ and angles $\left({ }^{\circ}\right)$ : $\mathrm{Cu}(1 \mathrm{~A})-\mathrm{N}(1 \mathrm{~A})$ 2.012(3), $\mathrm{Cu}(1 \mathrm{~A})-\mathrm{O}(1 \mathrm{~A}), 2.042(3)$, $\mathrm{Cu}(1 \mathrm{~A})-\mathrm{Cl}(1 \mathrm{~A})$ 2.253(1), $\mathrm{Cu}(1 \mathrm{~A})-\mathrm{Cl}(2 \mathrm{~A}) 2.216(1), \mathrm{Cu}(1 \mathrm{~A})-\mathrm{Cl}(1) 2.701(1), \mathrm{Cl}(1 \mathrm{~A})-\mathrm{Cu}(1) . \mathrm{Cl}(1)$ 92.41(4), $\mathrm{Cl}(2 \mathrm{~A})-\mathrm{Cu}(1)-\mathrm{Cl}(1) \quad 100.76(4), \mathrm{Cl}(2 \mathrm{~A})-\mathrm{Cu}(1)-\mathrm{Cl}(1 \mathrm{~A})$ 94.55(5), N(1)-Cu(1)-O(1) 
Journal Name

78.97(11). (Bottom) Perspective view of compound 2b showing the additional interactions. Selected bond distances $(\AA)$ and angles $\left({ }^{\circ}\right): \mathrm{Cu}(1)-\mathrm{Cl}(1) 2.315(1), \mathrm{Cu}(1)-\mathrm{N}(1)$ 1.989(2), Cu(1)-O(1) 2.380(2), Cl(1)-Cu(1)-O(1) 88.74(5), N(1)-Cu(1)-Cl(1) 90.24(6), N(1)$\mathrm{Cu}(1)-\mathrm{O}(1) 75.25(7)$ 


\section{Schiff condensation: metal conjugates with $\beta$-alanine}

As noted in the introduction, we have recently shown that the copper complex 1a is able to undergo aldol addition with ketones (Scheme 1a). ${ }^{37}$ We decided to explore the utility of complexes $\mathbf{1 a}$ and novel $\mathbf{1 b}$ in other nucleophilic reactions, such as the Schiff condensation reaction. We studied their reactivity towards $\beta$-alanine ( $\beta$-ala), which is the simplest amino acid, as well as the only naturally occurring $\beta$-amino acid. These studies would also be useful for assessing the possibilities of these complexes in bioconjugation.

Compound $\mathbf{1 b}$ reacts with $\beta$-alanine in methanol to ultimately afford compound $\mathbf{4}[\boldsymbol{\beta}$-ala], which was isolated from the red reaction crude as a few crystals. The single-crystal X-ray structure of $4[\beta$-ala] reveals the unexpected formation of an anionic $\mathrm{Cu}$ (II) complex that crystalizes with one molecule of protonated $\beta$-alanine, to which it is associated through two hydrogen bonds (Fig 3 ). The solid-state structure shows the expected formation of the iminopyridine derived from the Schiff condensation between the ketone group of acepy and the $\mathrm{NH}_{2}$ of $\beta$-ala. The carboxylate group of the iminopyridine is, however, deprotonated and coordinates to $\mathrm{Cu}(\mathrm{II})$ through one oxygen; thus, the iminopyridine ligand acts as $\mathrm{K}^{3}\left(\mathrm{~N}, \mathrm{~N}^{\prime}, \mathrm{O}\right)$. Two chloride ligands complete the coordination around the copper centre, forming a distorted square pyramidal complex (Addison parameter, $\tau=0.18){ }^{45}$
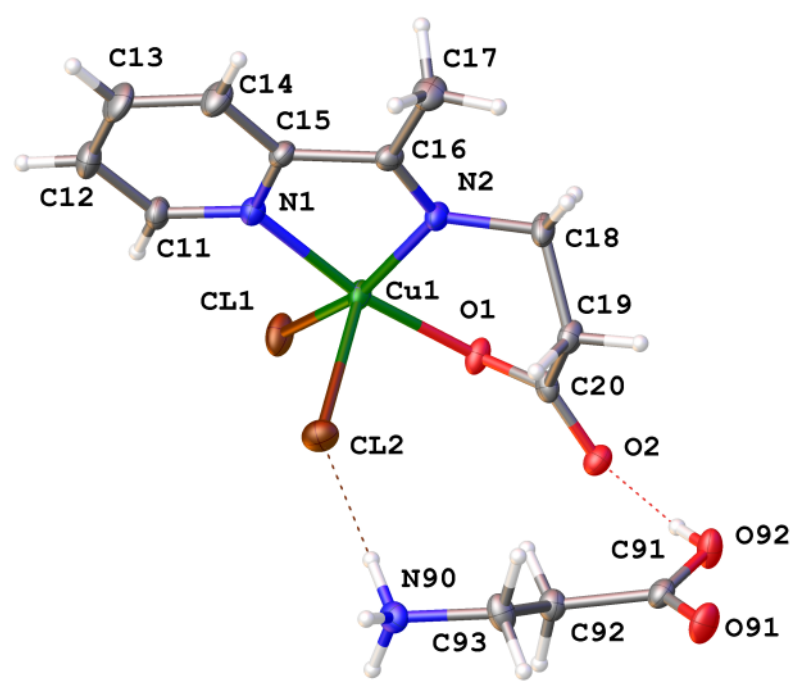

Fig. 3 Perspective view of compound $4[\beta$-alaH] showing the atom numbering. Selected bond distances $(\AA)$ and angles $\left({ }^{\circ}\right): \mathrm{Cu}(1)-\mathrm{Cl}(1) 2.249$ (1), $\mathrm{Cu}(1)-\mathrm{Cl}(2) 2.585(1), \mathrm{Cu}(1)-\mathrm{N}(1)$ 1.997(2), $\mathrm{Cu}(1)-\mathrm{N}(2)$ 1.987(2), $\mathrm{Cu}(1)-\mathrm{O}(1)$ 1.962(2), Cl(2)-H(90) 2.224, O(2)-H(92) 1,894, $\mathrm{Cl}(1)-\mathrm{Cu}(1)-\mathrm{Cl}(2)$ 104.72(3), N(1)-Cu(1)-Cl(1) 95.82(7), N(1)-Cu(1)-Cl(2) 91.98(7), N(2)$\mathrm{Cu}(1)-\mathrm{Cl}(1)$ 159.47(8), N(2)-Cu(1)-N(1) 80.46(9), O(1)-Cu(1)-N(2) 92.07(8).

It is tentatively proposed that reaction occurs through the formation of iminopyridine complex 3 (Scheme 2a), which presents a pendant free carboxylic terminus $(-\mathrm{COOH})$. The subsequent intramolecular nucleophilic attack of the carboxylic group without the loss of chloride produces the pentacoordinate anion 4, which crystalizes out with the protonated form of $\beta$-alanine as the counterion, as shown by the structure in Fig 3. Attempts to improve the yield by forcing the conditions ( $\mathrm{MeOH} / \mathrm{THF}$ reflux, $4 \mathrm{~h}$ ) were not successful. In all cases, $\mathbf{4}[\boldsymbol{\beta}$-alaH $]$ was isolated from the red reaction mixture as a few green crystals, indicating that the formation of the Schiff base is not favoured even under strong conditions.

In contrast to the acepy complex $\mathbf{1 b}$, complex $\mathbf{1} \mathbf{a}$, which was formed in-situ by mixing equimolar amounts of $\mathrm{CuCl}_{2} \cdot 2 \mathrm{H}_{2} \mathrm{O}$ and pyca, reacts smoothly at room temperature with one equivalent of $\beta$-ala in methanol. After $30 \mathrm{~min}$ at room temperature, a bright green solution is obtained, from which the corresponding iminopyridine complex 5 (Scheme $2 b$ ) could be isolated as a green microcrystalline solid in excellent yield (94\%). The fact that $\mathbf{1 a}$ is more reactive towards $\beta$-ala than $\mathbf{1 b}$ is not surprising given the higher electrophilicity and lesshindered nature of pyca compared to acepy. Crystals suitable for X-ray analysis were grown from $\mathrm{MeOH} / \mathrm{H}_{2} \mathrm{O}$. In the structure of 5 (Figure 4, above), the copper atom is bonded to two chlorides and a chelating $\kappa^{2}\left(\mathrm{~N}, \mathrm{~N}^{\prime}\right)$-iminopyridine ligand formed through the Schiff condensation of pyca and $\beta$-ala. In this case, the carboxylic acid is protonated and is not involved in coordination, unlike in the structure of complex 4 [ $\beta$-alaH] (Figure 3). Complex 5 can be viewed at first sight as a squareplanar complex, although in the solid it exhibits two additional interactions with the $\mathrm{O}$ and $\mathrm{Cl}$ atoms of neighbouring molecules, thus completing a tetragonally elongated octahedron around the copper atom. Additionally, a water molecule is present in the lattice, connecting the carboxylic O$\mathrm{H}$ and the chlorine atoms of neighbouring molecules (Figure 4, bottom).

The deprotonation of compound $\mathbf{5}$ can be easily accomplished with MeONa to produce the neutral complex 6 (Scheme 2b). The solid state structure of 6 (Figure 5, top) confirms the deprotonation of the carboxylic acid and subsequent intramolecular replacement of chloride by the carboxylate ligand that coordinates $\mathrm{Cu}(\mathrm{II})$ through one oxygen, thus, the 2pyridyl- $\beta$-alaninate ligand acts as $\mathrm{K}^{3}\left(\mathrm{~N}, \mathrm{~N}^{\prime}, \mathrm{O}\right)$, as observed in the structure of the anionic complex 4 . The structure of 6 presents a distorted square pyramidal geometry $(\tau=0.097)$, which includes a chloride atom and the iminopyridine ligand. The fifth position is occupied by an oxygen atom from the carboxylate, which produces an extended polymeric structure (see Figure 5 bottom). Here, the $\mathrm{Cu}(\mathrm{II})$ sits $0.192 \AA$ A outside the plane formed by $\mathrm{N}(1), \mathrm{N}(2), \mathrm{O}(1)$ and $\mathrm{Cl}(1)$.

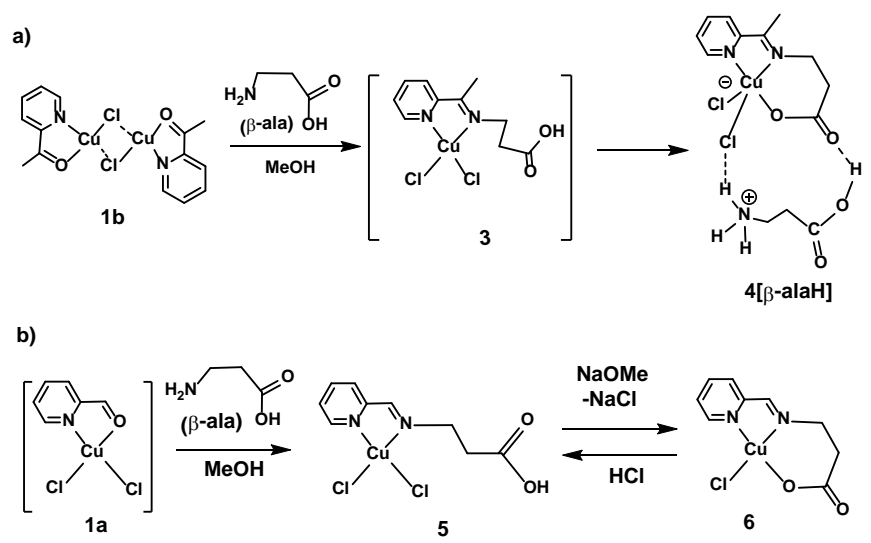

Scheme 2. Synthesis of copper complexes with 2-pyridine carboxaldehyde and iminopyridine $\beta$-alanine. 

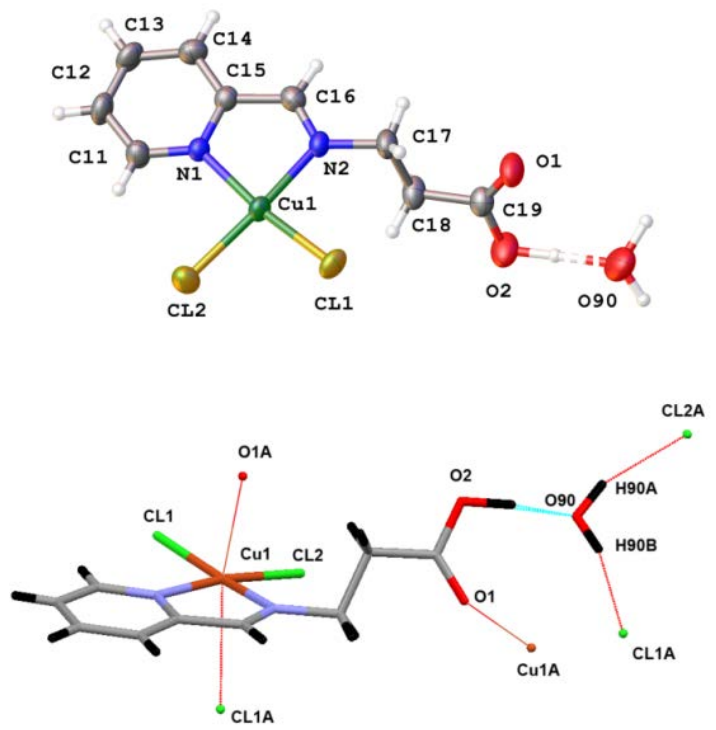

Fig. 4 (Top) Perspective view of compound 5 showing the atom numbering. Selected bond distances ( $(\AA)$ and angles $\left({ }^{\circ}\right): \mathrm{Cu}(1)-\mathrm{Cl}(1) 2.268(1), \mathrm{Cu}(1)-\mathrm{Cl}(2) 2.258(1), \mathrm{Cu}(1)-\mathrm{N}(1)$ 2.029(2), $\mathrm{Cu}(1)-\mathrm{N}(2)$ 2.030(2), $\mathrm{Cl}(1)-\mathrm{Cu}(1)-\mathrm{Cl}(2)$ 92.88(3), $\mathrm{Cl}(1)-\mathrm{Cu}(1)-\mathrm{N}(2) 94.71(7), \mathrm{Cl}(2)-$ $\mathrm{Cu}(1)-\mathrm{N}(1)$ 92.74(7), N(1)-Cu(1)-N(2) 80.36(9). (Bottom) Perspective view of compound 5 showing the additional interactions. Selected bond distances $(\AA)$ and angles $\left({ }^{\circ}\right): \mathrm{Cu}(1)$ $\mathrm{O}(1 \mathrm{~A})$ 2.652(3), $\mathrm{Cu}(1)-\mathrm{Cl}(1 \mathrm{~A})$ 2.981(1), O(2)-O(90) 2.616(4), O(90)-Cl(2A) 3.204(4), $\mathrm{O}(90)-\mathrm{Cl}(1 \mathrm{~A}) 3.241(3), \mathrm{O}(2)-\mathrm{H}(2)-\mathrm{O}(90)$ 175.1(2), O(90)-H(90A)-Cl(2A) 168.5(2), O(90)$\mathrm{H}(90 \mathrm{~B})-\mathrm{Cl}(1 \mathrm{~A})$ 165.7(2).

UV-VIS titration studies demonstrated that the reaction is fully reversible (see ESI). The addition of $\mathrm{HCl}$ to 6 to generate 5 was followed using UV-VIS, and showed the opening of the $\beta$ alanine chain to form $\mathbf{5}$ upon addition of $\mathrm{HCl}$ to a solution of 6 in methanol. This is particularly interesting, since it indicates that the reversible switching of the coordination mode from $\mathrm{K}^{3}\left(\mathrm{~N}, \mathrm{~N}^{\prime}, \mathrm{O}\right)$ to $\mathrm{K}^{2}\left(\mathrm{~N}, \mathrm{~N}^{\prime}\right)$ can be triggered by simply manipulating the $\mathrm{pH}$ (Scheme $2 \mathrm{~b}$ ). It also demonstrates the robustness of the complex towards acids and bases $(\mathrm{HCl}, \mathrm{NaOH})$. These features are particularly interesting for the potential use of these complexes as MRI agents (see later discussion).
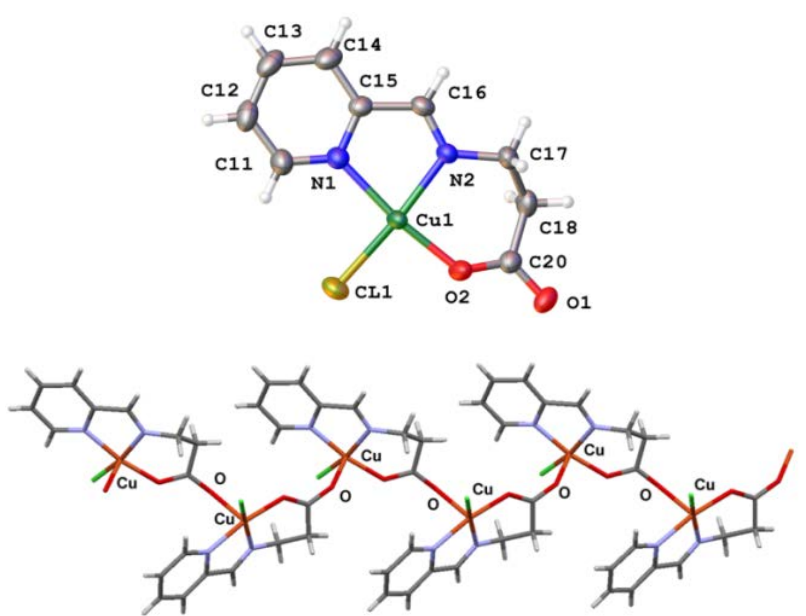

Fig. 5 (Top) Perspective view of the "monomer" of compound 6 showing the atom numbering. Selected bond distances $(\AA ̊)$ and angles $\left({ }^{\circ}\right): \mathrm{Cu}(1)-\mathrm{Cl}(1) 2.254(1), \mathrm{Cu}(1)-\mathrm{N}(1)$ 2.040(2), $\mathrm{Cu}(1)-\mathrm{N}(2)$ 1.983(2), $\mathrm{Cu}(1)-\mathrm{O}(1)$ 1.937(2), $\mathrm{Cl}(1)-\mathrm{Cu}(1)-\mathrm{O}(1)$ 91.62(6), $\mathrm{Cl}(1)-$ $\mathrm{Cu}(1)-\mathrm{N}(1)$ 94.26(7), N(1)-Cu(1)-N(2) 80.30(9), N(2)-Cu(1)-O(1) 92.13(8). (Bottom) Extended polymeric structure of compound 6 in the solid phase. The copper atoms attain pentacoordination through long $\mathrm{Cu}-\mathrm{O}(2)$ bonds of $2.303 \AA$ ( $c f$. Cu-O(1) $1.937 \AA$ ).

\section{Aldol reaction and hemiacetal formation promoted by $\mathrm{Cu}(\mathrm{II})$ and $\mathrm{Cu}(\mathrm{I})$ reactions}

As background for this study, we also explored the reactivity of $\mathrm{Cu}^{\prime} \mathrm{Cl}$ with pyca and acepy towards nucleophilic additions. Upon mixing $\mathrm{Cu}^{\prime} \mathrm{Cl}$ with pyca in methanol under aerobic conditions (Scheme 3), the solid dissolves quickly to give a colourless solution. However, this solution gradually takes on the green colour characteristic of $\mathrm{Cu}^{\prime \prime}$. After 15 minutes, the complete precipitation of green $\mathbf{7}$ is produced. Contrary to our expectations, the solid-state structure of $\mathbf{7}$ is a dimeric $\mathrm{Cu}^{\prime \prime}$ complex with two coordinated and deprotonated methanol hemiacetal ligands derived from pyca (see Scheme 3 and ESI for the structural characterization). Compound 7 had been previously obtained as the unexpected product of the reaction of 4-iodo-N-(2-pyridylmethylene)-aniline with $\mathrm{CuCl}^{46}$

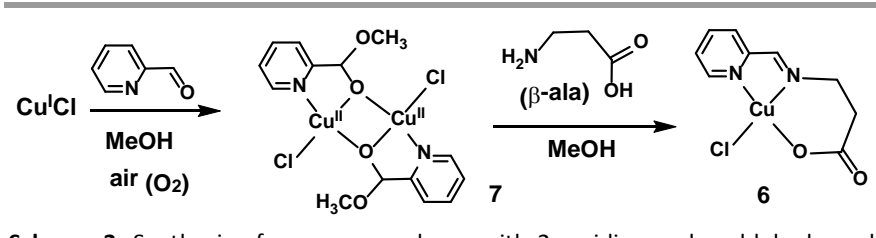

Scheme 3. Synthesis of copper complexes with 2-pyridine carboxaldehyde and iminopyridine $\beta$-alanine.

A tentative mechanism for the formation of $\mathbf{7}$ is depicted in Scheme 4. In alcohols, aldehydes are in equilibrium with hemiacetals; ${ }^{47,48}$ this is also the situation for the pyca ligand in $\mathrm{MeOH}$ (see Fig S3-S4/ESI). The presence of the Lewis acid centre $\mathrm{Cu}(\mathrm{I})$ would help to promote the nucleophilic attack of $\mathrm{MeOH}$ on the aldehyde group of pyca via metal coordination. A soluble $\mathrm{Cu}(\mathrm{I}) /$ pyca complex could conceivably be formed in the first step, after which the copper would be oxidized to $\mathrm{Cu}(\mathrm{II})$ by atmospheric oxygen, providing the basic medium that promotes the deprotonation of the hemiacetal (equation 1 ):

$$
2 \mathrm{Cu}^{+}+1 / 2 \mathrm{O}_{2}+\mathrm{H}_{2} \mathrm{O} \longrightarrow 2 \mathrm{Cu}^{2+}+2 \mathrm{OH}^{-} \text {eq } 1
$$

Indeed, complex 7 can be also obtained in virtually quantitative yield from $\mathrm{CuCl}_{2}$ via the reaction of complex 1a with sodium methoxide in methanol (see Fig S5/ESI for comparison of the X-ray powder diffraction analysis (XRPD)). It has been reported that the stabilization of the hemiacetal species may be promoted via the coordination of Lewis acids, ${ }^{49,50}$ strong hydrogen bonds ${ }^{51}$ and metal ions. ${ }^{52,53}$ In this vein, copper (II) is an excellent electron acceptor for nitrogen atoms and hydroxyl groups, ${ }^{54,55}$ and could thus allow stabilisation of the otherwise highly reactive deprotonated methanol hemiacetal pyridyl ligand in complex $\mathbf{7}$ (which is not stable as a free species). This, together with the poor solubility of the final product in $\mathrm{MeOH}$, is likely to be the driving force for the formation of $\mathbf{7}$.

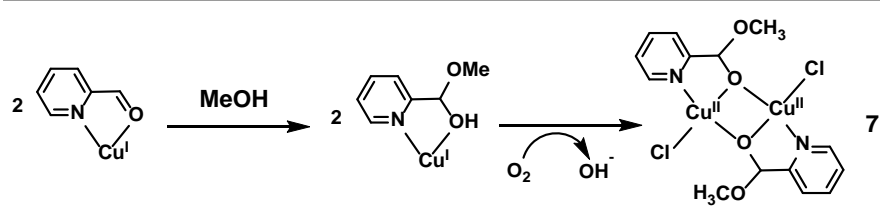

Scheme 4. Mechanism of the synthesis of complex 7. 
Remarkably, the formation of the hemiacetal alkoxide complex 7 does not completely preclude nucleophilic attack by the amine, and complex 7 undergoes Schiff formation with $\beta$-ala. Complex $\mathbf{7}$ is slowly dissolved upon treatment with $\beta$-alanine in methanol to yield a deep green solution from which compound 6 could be isolated as green microcrystals (see Scheme 3).

Interestingly, when acepy is reacted with $\mathrm{Cu}^{\prime} \mathrm{Cl}$ in methanol, the clean precipitation of complex 8 occurs after $2 \mathrm{~h}$ at room temperature, which was isolated in virtually quantitative yield (Scheme 5). The single-crystal X-ray structure of 8 reveals the unexpected formation of an all-Cu(II) tetramer (see Figure 6).
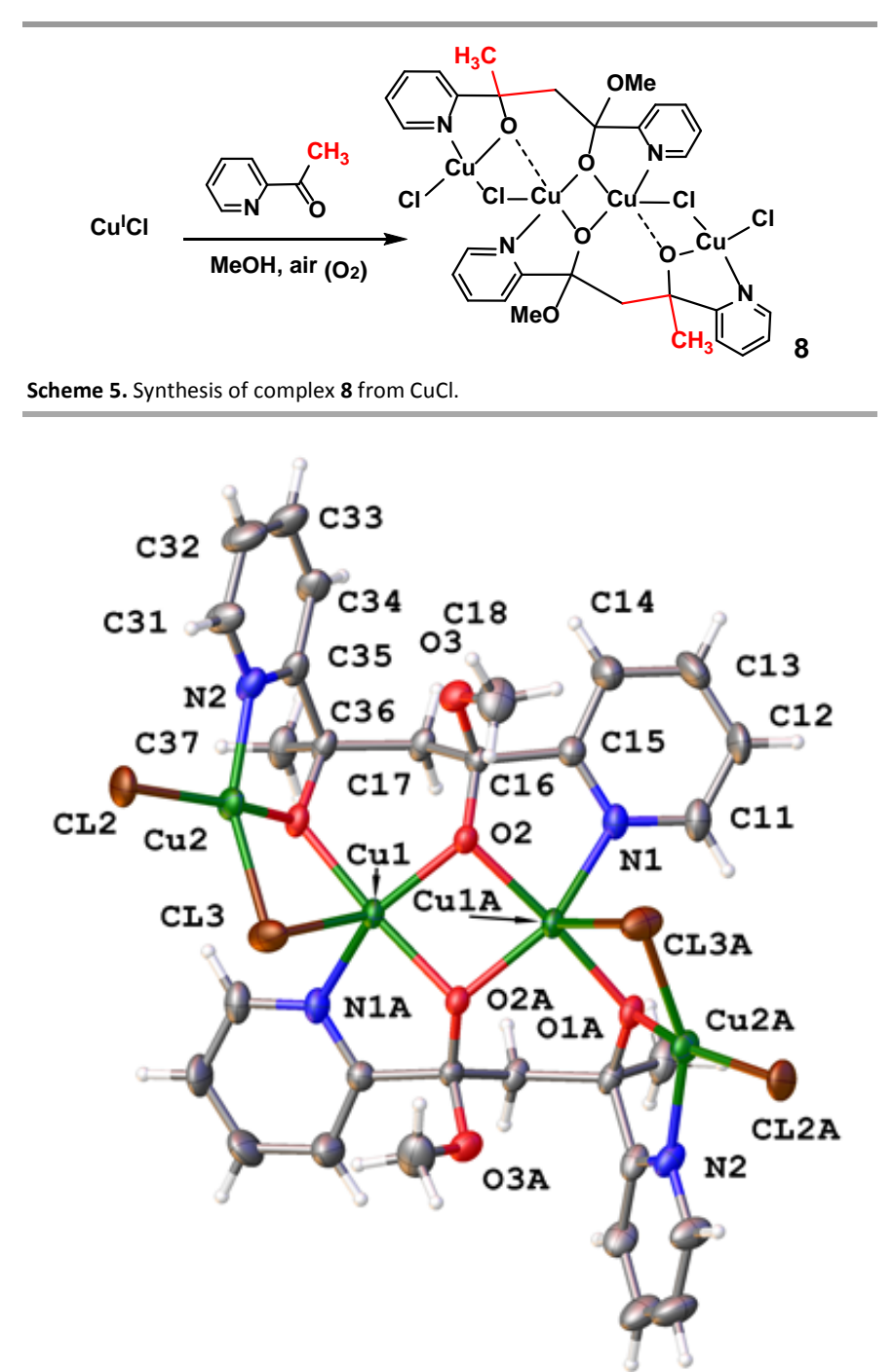

Fig. 6 Structure of 8 showing the atom numbering. Selected bond lengths (Å) and angles $\left({ }^{\circ}\right): \mathrm{Cu}(2)-\mathrm{Cl}(2)$ 2.217(2), $\mathrm{Cu}(2)-\mathrm{Cl}(3)$ 2.274(3), $\mathrm{Cu}(2)-\mathrm{N}(2)$ 1.960(8), $\mathrm{Cu}(2)-\mathrm{O}(1)$ 1.920(5), $\mathrm{Cu}(1)-\mathrm{Cl}(3)$ 2.587(3), $\mathrm{Cu}(1)-\mathrm{O}(1)$ 1.922(5), $\mathrm{Cu}(1)-\mathrm{O}(2)$ 1.942(5), $\mathrm{Cu}(1)-\mathrm{O}(2 \mathrm{~A})$ 1.948(5), $\mathrm{Cu}(1)-\mathrm{Cu}(1 \mathrm{~A})$ 2.853(2), $\mathrm{Cu}(1)-\mathrm{Cu}(2)$ 3.107(1), N(2)-Cu(2)-O(1) 101.4(3), O(1)$\mathrm{Cu}(2)-\mathrm{Cl}(3)$ 88.95(18), O(1)-Cu(1)-Cl(3) 80.25(17), O(2)-Cu(1)-O(2A) 82.4(2).

The structure shows the formation of a dianionic ligand, which results from a self-aldol addition in which two molecules of acepy react to produce an aldol ( $\beta$-hydroxy ketone). This ligand coordinates via the $\mathrm{N}$ and $\mathrm{O}$ atoms. The in-situ formation of two alkoxides favours the bridging of several $\mathrm{Cu}$ centres to accommodate the negative charge. This feature, along with the tetradentate nature of the ligand and its relatively rigid structure, prevents its coordination to a single metal and favours the formation of a stable polynuclear complex.

A tentative mechanism for the formation of the tetrameric complex $\mathbf{8}$ is depicted in Scheme 6. The addition of methanol to the ketone would result in the formation of a hemiacetal, as was also observed in the synthesis of 7 . In both processes, the coordination to copper and the basic media resulting from the oxidation of $\mathrm{Cu}(\mathrm{I})$ to $\mathrm{Cu}(\mathrm{II})$ favoured the stabilization of the alkoxide. The key difference between the formation of $\mathbf{7}$ and $\mathbf{8}$ was the less nucleophilic character of acepy and the presence of acidic hydrogen atoms, which made self-aldol addition possible. The deprotonation of acepy is facilitated by the coordination of acepy to copper and by the mildly basic media resulting from $\mathrm{Cu}(\mathrm{I})$ oxidation. Nucleophilic attack of a second acepy molecule (self-aldol addition) would lead to the formation of a $\beta$-alkoxy ketone, in which the negative charge of the alkoxide ligand would be stabilised via metal coordination. The carbonyl group undergoes hemiacetal formation mediated by $\mathrm{Cu}$ coordination, and the $\mathrm{OH}$ group is deprotonated to bind as a $\mu_{2}$ bridging ligand, which is not surprising based on the previous discussion.

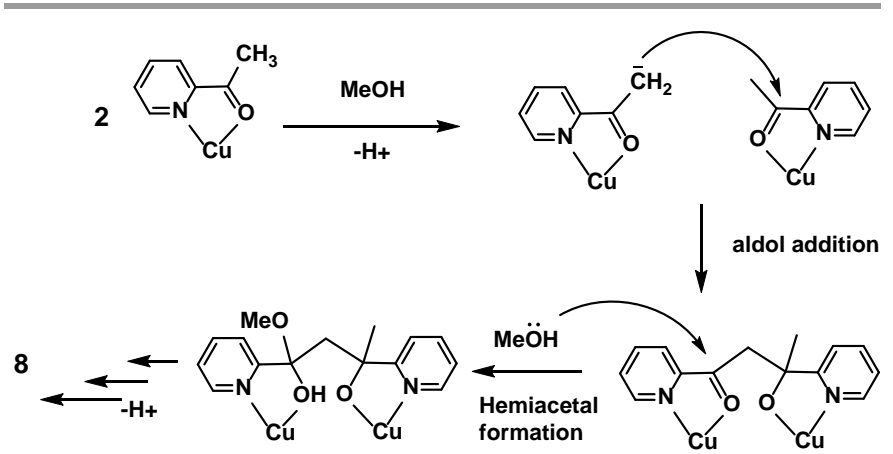

Scheme 6. Suggested pathway for the formation of 8 .

Further evidence for this mechanism came from the reaction of $\mathrm{Cu}^{\text {"l }}$ complex $\mathbf{1 b}$ in THF and basic media (1 eqv $\mathrm{KOH}$ ), which results in the formation of 8 in $92 \%$ yield. It is interesting to note that prolonged storage of $\mathbf{1 b}$ in THF at ambient temperature slowly yielded a few crystals of $\mathbf{8}$. This indicates that the coordination of acepy to $\mathrm{Cu}^{\text {II }}$ increases the acidity of the $\mathrm{CH}_{3}$ group in acepy, favouring enolate formation (even in the absence of a base), which ultimately produces 8 via an aldol-type reaction. However, this also indicates that the formation of such an enolate could be partly responsible for the low yield observed for the Schiff reaction of $\mathbf{1} \mathbf{b}$ and $\beta$-ala (see Scheme 2a, above).

Aldol addition between two acepy molecules to produce the corresponding neutral $\beta$-hydroxy ketone ( $\left.\mathrm{HL}^{\prime}\right)$ ligand was observed by Perlepees et al. under strongly basic conditions. ${ }^{54}$ Upon reaction with $\mathrm{Cu}\left(\mathrm{ClO}_{4}\right)_{2} \cdot 6 \mathrm{H}_{2} \mathrm{O}$, a mixture of complexes was formed, including $\left.\left[\mathrm{Cu}_{2} \mathrm{Cl}_{2}\left(\mathrm{~L}^{\prime}\right)_{2}\right]\left(\mathrm{ClO}_{4}\right)_{2}\right]$. The presence of chloro ligands in addition to the original $\mathrm{ClO}_{4}$ in the $\mathrm{Cu}(\mathrm{II})$ coordination sphere was proposed to arise via the loss of chloride from $\mathrm{CHCl}_{3}$ (used as a solvent) under such strongly 
basic conditions. In a similar vein, Datta et al. ${ }^{56}$ prepared a dinuclear dimeric complex, $\left[\mathrm{Cu}_{2}(\mathrm{HL})_{2}\right]\left(\mathrm{ClO}_{4}\right)_{2}$, by the oxidation of $\left[\mathrm{Cu}^{\prime}(\text { acepy })_{2}\right] \mathrm{ClO}_{4}$ with $\mathrm{H}_{2} \mathrm{O}_{2}$ in $\mathrm{MeOH}$, where $\mathrm{HL}$ is a monoanionic ligand that results from aldol addition between two acepy molecules and hemiacetal formation. Our results show that the $\mathrm{Cu}$ metal precursor has a crucial impact on the association and nuclearity of the final complex. While the presence of weakly coordinating $\mathrm{ClO}_{4}$ ligands appears to promote the formation of dimeric complexes, as observed by Perlepees and Datta for two related ligands, the use of $\mathrm{CuCl}$ or $\mathrm{CuCl}_{2}$ both yielded the formation of the tetrameric all-Cu(II) complex $\mathbf{8}$. In this case, the more strongly coordinating anion $\left(\mathrm{Cl}^{-}\right)$results in the formation of a neutral tetrameric complex presenting two dianionic $\mathrm{L}^{2-}$ ligands, in which all the original chloride ligands remain coordinated to copper: two as terminal chloride ligands and two via $\mu^{2}$ bridging. On a similar note, we have recently shown that the selection of the $\mathrm{Cu}(\mathrm{II})$ salt crucially determines the product of the $\mathrm{Cu}(\mathrm{II})$-mediated crossaldol reactions of pyca and different ketones, with double aldol addition occurring when a copper precursor of sufficient Lewis acidity, such as $\mathrm{Cu}\left(\mathrm{ClO}_{4}\right) \cdot 6 \mathrm{H}_{2} \mathrm{O}$, is used. ${ }^{37}$

\section{Complex derivatization of $\beta$-ala bioconjugates}

The $\beta$-alanine bioconjugate complex $\mathbf{7}$, with one halogen in the coordination sphere of the metal, is ideally suited for the study of not only the structural effect of the introduction of a different halogen/pseudohalogen but also the influence of such a change on the magnetic and cytotoxic properties of the complex in a systematic way. Altering the complex by substituting a pseudohalogen could provide an easy way to tune the magnetic and cytotoxic properties of the complex. In addition to this, the $\mathrm{pH}$-dependent behaviour of $\mathbf{7}$ (see Scheme 2b) could have advantages due to its facile interconversion between the closed and open species in solution, which could favour its interaction with water molecules and improve its response to MRI.

The substitution of the chloride in complex 6 by other ligands allows the preparation of complexes with thiocyanate (9), azide (10a) and (10b), and cyanate (11) upon reaction of 6 with the corresponding sodium salt (Scheme 7).

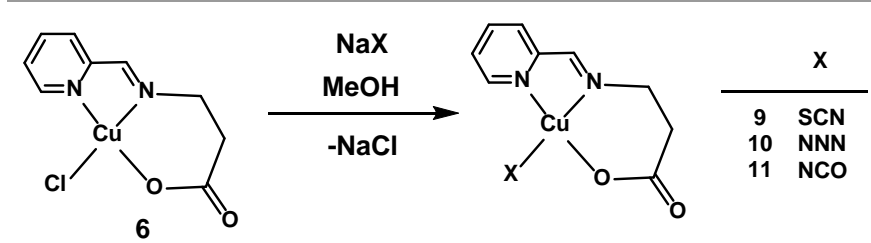

Scheme 7. Derivatization of 6 to obtain complexes 9-11.

The thiocyanate complex 9, in which thiocyanate $\left(\mathrm{SCN}^{-}\right)$ coordinates copper through the $\mathrm{N}$ atom, presents a distorted square pyramidal geometry with the copper atom displaced $0.117 \AA$ from the basal plane. The coordination of the methanol molecule in the apical position prevents the formation of a polymeric structure such as that in complex 6 (Figure 8 ). Compound $\mathbf{1 0}$ crystallizes in two polymorphs, 10a and 10b, which present different extended structures in the solid state, as confirmed by $\mathrm{X}$-ray diffraction.

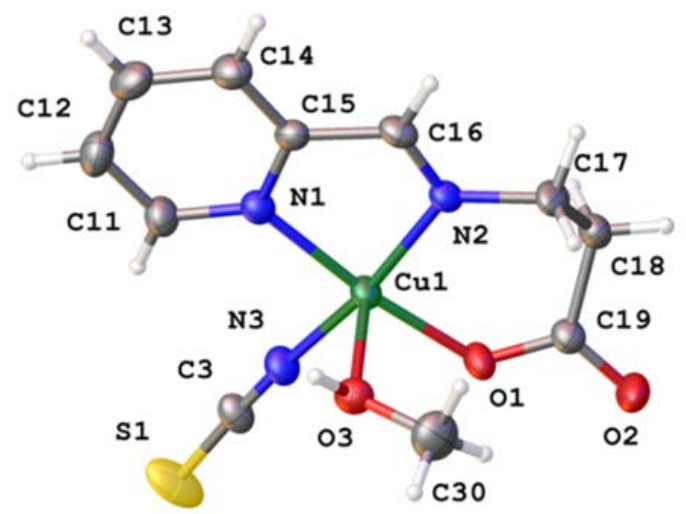

Fig. 8 Perspective view of compound 9 showing the atom numbering. Selected bond distances (Å) and angles ( ${ }^{\circ}$ ): $\mathrm{Cu}(1)-\mathrm{N}(1)$ 2.013(3), $\mathrm{Cu}(1)-\mathrm{N}(2)$ 1.969(3), $\mathrm{Cu}(1)-\mathrm{N}(3)$ 1.955(3), $\mathrm{Cu}(1)-\mathrm{O}(1)$ 1.925(2), $\mathrm{Cu}(1)-\mathrm{O}(3)$ 2.288(2), N(3)-Cu(1)-N(1) 95.19(11), N(1)$\mathrm{Cu}(1)-\mathrm{N}(2) 81.07(11), \mathrm{N}(2)-\mathrm{Cu}(1)-\mathrm{O}(1) 92.50(10), \mathrm{N}(3)-\mathrm{Cu}(1)-\mathrm{O}(1) 90.74(10) . \tau=0.08$

Although these extended structures are quite different, superposition of the monomer units of each shows that, apart from the obvious difference in the aliphatic carbons of the $\beta$ alanine residue, the monomeric conformations are quite similar for both structures (Fig 9). As shown in Figure 10, in the polymorph 10a, the copper atom is coordinated to an oxygen of the carboxylate of a neighbouring molecule as found in previous structures, while in $\mathbf{1 0 b}$ there is an additional end-on azide bridge which results in a hexacoordinate (tetragonally elongated octahedron) copper atom, whereas 10 a can be considered to be pentacoordinate (distorted square pyramid with $\tau=0.083$ ).
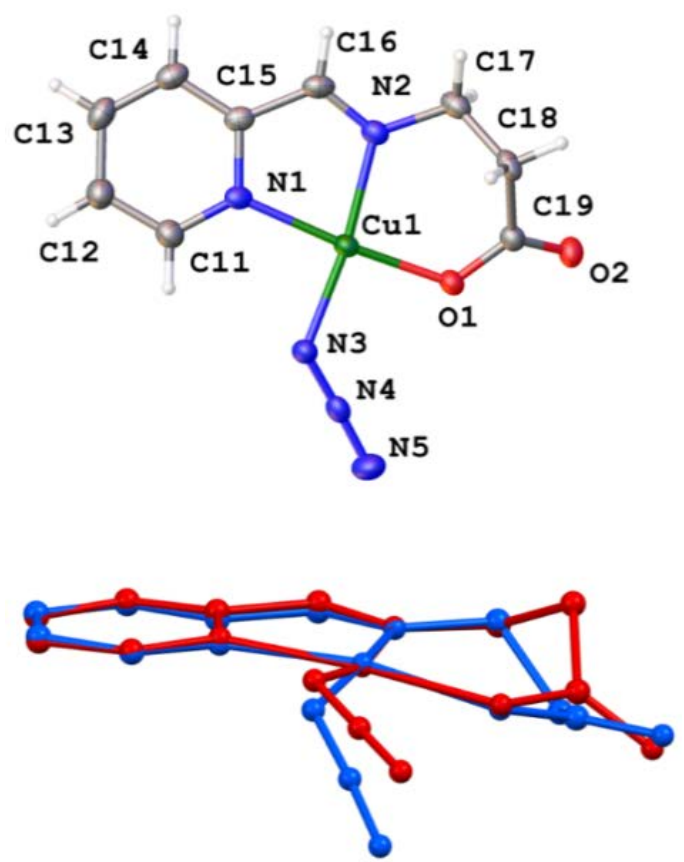

Figure 9. (Top) Perspective view of the "monomer" of compound 10b showing the atom numbering. Selected bond distances $(\AA)$ and angles $\left({ }^{\circ}\right)$ : $\mathrm{Cu}(1)-\mathrm{N}(1)$ 2.025(3), Cu(1)-N(2) 1.995(3), Cu(1)-N(3) 1.977(3), Cu(1)-O(1) 1.938(3), N(3)- 
$\mathrm{Cu}(1)-\mathrm{N}(1)$ 92.26(15), N(1)-Cu(1)-N(2) 80.25(14), N(2)-Cu(1)-O(1) 95.08(13), N(3)$\mathrm{Cu}(1)-\mathrm{O}(1)$ 93.16(13). (Bottom) Overlay (MERCURY) of the conformations of the monomers in the structures of the two azide complexes 10a (blue) and 10b (red).

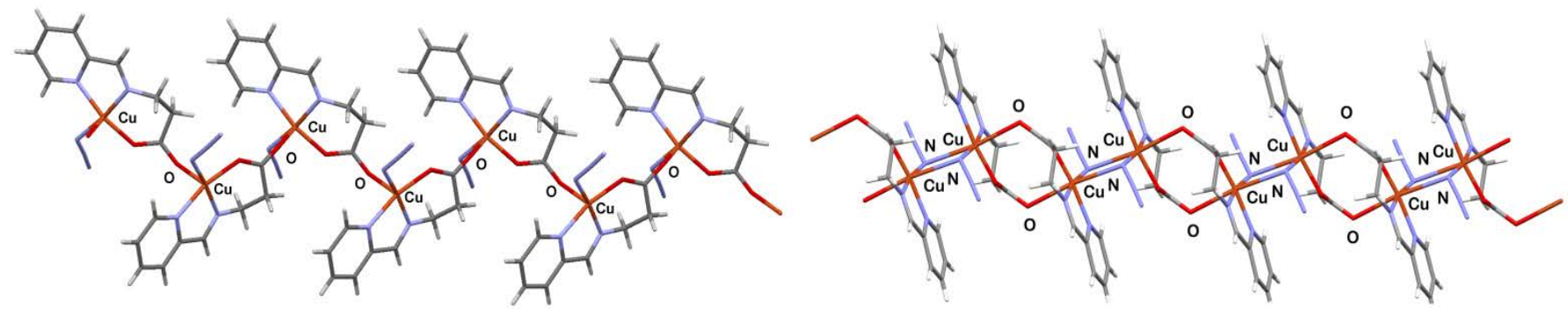

Fig. 10 (Left) Extended polymeric structure of compound 10a in the solid phase. The copper atoms attain pentacoordination through bonding with the oxygen of the carboxylate ( $\mathrm{Cu}(1)-\mathrm{O}^{\prime}$ is $2.255 \AA$ A). It can be seen as a zig-zag polymer. (Right) Extended polymeric structure of compound 10b in the solid phase. The copper atoms attain hexacoordination through alternating coordination to the oxygen of the carboxylate ( $\mathrm{Cu}(1)-\mathrm{O}^{\prime}$ is $2.496 \AA$ ) and the $\mathrm{N}$ atom of the azide ligand (Cu(1)- $\mathrm{N}^{\prime}$ is $2.715 \AA$ ). It can be seen as a chain of asymmetric azide-bridged dimers with $\mathrm{Cu}(1)-\mathrm{Cu}(2) 3.487 \AA$, $\mathrm{Cu}(1)-\mathrm{N}(1)-\mathrm{Cu}(2) 94.71$

Complex $\mathbf{1 0 b}$ is a kinetic product and can be obtained after the reaction described in the experimental part (and confirmed by XPRD studies). Slow crystallization in $\mathrm{MeOH} / \mathrm{ether}$ or $\mathrm{H}_{2} \mathrm{O} / \mathrm{MeOH} /$ ether is required to obtain complex 10a (the thermodynamic product), and even in this case, the crystals are accompanied by variable amounts of polymorph $\mathbf{1 0 b}$.

In the case of complex 11, cyanate $\left(\mathrm{NCO}^{-}\right)$is $\mathrm{N}$-bonded to copper and the molecule can be viewed as planar tetracoordinated (Figure 11, above) with the metallic centre displaced $0.169 \AA$ from the basal plane. As in previous cases, in the extended structure, the copper atom attains pentacoordination through the oxygen atom of the carboxylate function of a neighbouring molecule (Figure 11, bottom).

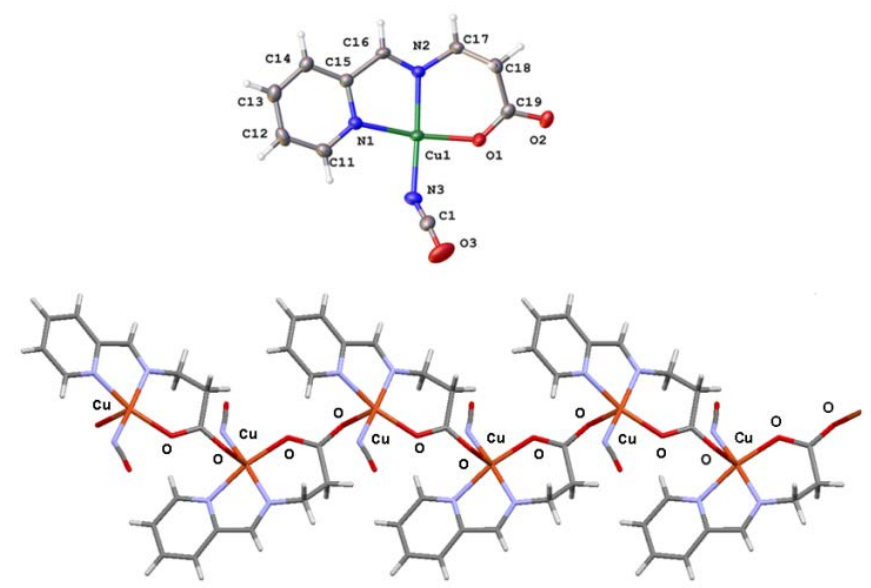

Figure 11. (Top) Perspective view of the "monomer" of compound $\mathbf{1 1}$ showing the atom numbering. Selected bond distances $(\AA)$ and angles $\left({ }^{\circ}\right): \mathrm{Cu}(1)-\mathrm{N}(1) 2.033(2), \mathrm{Cu}(1)$ $\mathrm{N}(2) 1.978(2), \mathrm{Cu}(1)-\mathrm{N}(3)$ 1.979(3), $\mathrm{Cu}(1)-\mathrm{O}(1)$ 1.938(2), N(3)-Cu(1)-N(1) 94.47(10), N(1)$\mathrm{Cu}(1)-\mathrm{N}(2)$ 80.35(9), N(2)-Cu(1)-O(1) 92.40(9), N(3)-Cu(1)-O(1) 91.13(10). (Bottom) Extended polymeric structure of compound 8 in the solid phase. The copper atoms attain pentacoordination through long $\mathrm{Cu}-\mathrm{O}(2)$ bonds of $2.264 \AA$ ( $c f$. Cu-O(1) $1.937 \AA$ ) in a fashion similar to compounds 5 and 7 a. $\tau=0.037$

\section{Magnetic Measurements}

The magnetic properties of the copper complexes $\mathbf{5}, \mathbf{6}, \mathbf{7}, \mathbf{9}$, $\mathbf{1 0 b}$ and 11 were investigated, and they correlated well with that expected from their solid-state structures, discussed previously. With the exception of complex $\mathbf{7}$, which presents very strong antiferromagnetic coupling between the two copper (II) centres via a superexchange mechanism through the oxo-bridges (ESI Figure S17), the complexes show weak ferromagnetic or weak antiferromagnetic coupling. Table 1 shows that the Curie constants for 5, 6, 9, 10b and $\mathbf{1 1}$ are in the range $0.44-0.47 \mathrm{emu} \cdot \mathrm{K} \cdot \mathrm{mol}^{-1}$, which is in agreement with the expected values for one $\mathrm{Cu}(\mathrm{II})$ ion per formula unit. ${ }^{57}$ Compounds $\mathbf{5}$ and $\mathbf{9}$ behave as isolated complexes with weak intermolecular antiferromagnetic coupling (see ESI). Compound $\mathbf{6}$ exhibits intramolecular antiferromagnetic behaviour; its magnetic properties can be described using a model for regular antiferromagnetic $S=1 / 2$ spin chains (see ESI $\mathrm{S} 19)$. In the case of complex 10b, an interaction that is most probably ferromagnetic is observed, which can be ascribed to the very small $\mathrm{Cu}-\mathrm{N}-\mathrm{Cu}$ angle found in its solid structure (see Figure S20, ESI). Finally, compound $\mathbf{1 1}$ presents a slight intramolecular ferromagnetic coupling owing to its anti-anti carboxylate arrangement (see ESI). This kind of behaviour has previously been found in some anti-anti carboxylate complexes. $^{38,39,58}$

Table 1. Curie constant and Weiss temperature for compounds 5, 6, 9, 10b and $\mathbf{1 1}$.

\begin{tabular}{|c|c|c|c|c|c|}
\hline & $\mathbf{5}$ & $\mathbf{6}$ & $\mathbf{9}$ & $\mathbf{1 0 b}$ & $\mathbf{1 1}$ \\
\hline $\mathrm{C}\left(\mathrm{emu} \cdot \mathrm{K} \cdot \mathrm{mol}^{-1}\right)$ & $0.45(1)$ & $0.44(1)$ & $0.45(1)$ & $0.47(1)$ & $0.48(1)$ \\
\hline$\theta(\mathrm{K})$ & $-0.11(1)$ & $-0.13(1)$ & $0.00(5)$ & $-1.07(5)$ & $0.27(3)$ \\
\hline
\end{tabular}

\section{Relaxivity measurements}

Although less paramagnetic than $\mathrm{Gd}^{3+}$, easy available $\mathrm{Cu}(\mathrm{II})$ complexes have attracted attention due to their much lower comparative toxicity and cost. For instance, complexes based on paramagnetic chemical exchange saturation transfer (PARACEST), ${ }^{59,} 60$ which contain groups that can exchange protons with water (i.e. $\mathrm{OH}$ groups), including $\mathrm{Cu}(\mathrm{II})$ complexes, have recently been reported as promising magnetic resonance imaging (MRI) agent. ${ }^{27}$

The relaxivity $\left(r_{1}\right)$ of the complexes 5, 6, 9, 10b and $\mathbf{1 1}$ bearing an iminopirydine ligand derived from $\beta$-ala were measured. The "open" complex 5 and "closed" complexes 6, 9, 10b and 11 , in which different halogen $(\mathrm{Cl})$ or pseudohalogens $\left(\mathrm{N}_{3} \mathrm{NCO}\right.$, and $\mathrm{SCN}$, respectively) completes the coordination 
environment of $\mathrm{Cu}(\mathrm{II})$, are well suited to evaluate the effect of small structural changes on the relaxivity of the complex. All the complexes were soluble in $\mathrm{D}_{2} \mathrm{O}$ and in phosphate-buffered saline (PBS), and were found to be stable for months under aerobic conditions. Preliminary measurements were undertaken in a 11.7 T NMR instrument to identify the most promising candidates for more in-depth studies. The relaxivity $\left(r_{1}\right)$ of the complexes $5,6,9,10 b$ and 11 was measured in $D_{2} O$ (see ESI, Table S1) at a fixed concentration of $10 \mathrm{mM}$. The copper (II) chloride complexes 5 and $\mathbf{6}$ gave the most promising values $\left(r_{1}\right.$ values of $0.52 \mathrm{mM}^{-1} \mathrm{~s}^{-1}$ and $0.33 \mathrm{mM}^{-1} \mathrm{~s}^{-1}$, respectively). The better $T_{1}$-relaxivity values found for the chloride complexes could be due to the greater lability of this ligand as compared with the pseudohalogens in aqueous media, which might facilitate improved interaction with water molecules. As noted in the introduction, Luxol fast blue (LFB), a well-known histological stain, has been tested as an MRI contrast agent, and shows an $r_{1}$ value of $0.09 \mathrm{mM}^{-1} \mathrm{~s}^{-1}$ (aqueous solution at $4.7 \mathrm{~T}) .^{28}$ The present complexes display relaxivities higher than those measured for LFB and comparable with those reported for other $\mathrm{Cu}(\mathrm{II})$ complexes containing $\mathrm{N}$ or $\mathrm{O}$ donor ligands that have complicated structures or are more difficult to obtain. ${ }^{61-63}$ For instance, Reglinski and Spickett et al. reported relaxivities in the range of $0.11-0.42 \mathrm{mM}^{-1} \mathrm{~s}^{-1}$ for $\mathrm{N}$ substituted macrocyclic $\mathrm{Cu}(\mathrm{II})$ complexes $(9.4 \mathrm{~T}, 0.1 \mathrm{M} \mathrm{NaCl}$ in $\mathrm{D}_{2} \mathrm{O}$ ).

Motivated by these results, we performed measurements for 5 and 6 in a $9.4 \mathrm{~T}$ pre-clinical MRI system in PBS at concentrations of 0-50 $\mathrm{mM}$ (see ESI). The $\mathrm{T}_{1}$-relaxivity values $\left(r_{1}\right)$ were calculated by plotting $1 / T_{1}$ as a function of concentration, which gave values of 0.3798 and $0.2979 \mathrm{mM}^{-1} \mathrm{~s}$ ${ }^{1}$, respectively. The phantom images of complex $\mathbf{5}$ at different concentrations demonstrating the optical changes associated with relaxivity are shown in Fig. 12. Complex $\mathbf{5}$ displays brighter $\mathrm{T}_{1}$-weighted $\mathrm{MRI}$ images with increasing molar concentration.

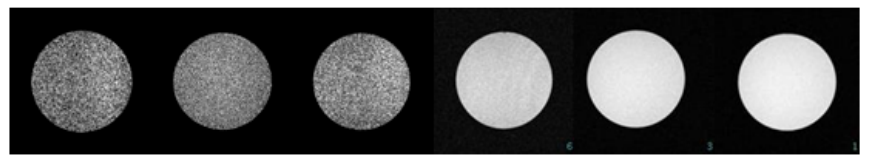

PBS $\quad 0,4 \mathrm{mM} \quad 1 \mathrm{mM} \quad 10 \mathrm{mM} \quad 30 \mathrm{mM} \quad 50 \mathrm{mM}$

Figure 12. Selected $T_{1}$-weighted phantom images of complex $\mathbf{5}$ at different concentrations (0-50 mM).

\section{Cytotoxicity/cell proliferation assay}

A preliminary test of the cytotoxic activity of the iminopyridine complexes derived from $\beta$-ala $\mathbf{6}$ and $\mathbf{1 0}$ against Chinese hamster ovary ( $\mathrm{CHO}$ ) and human (HELA) cell lines has been performed. The cell viability was evaluated using the MTT assay (see ESI for details), and Table 2 shows the obtained IC 50 values. Both complexes exhibit comparable activity against HELA cells (6: $37.55 \pm 2.35,10 b: 42.74 \pm 3.99 \mu \mathrm{M})$. Although these values are relatively high, the activity of complex $\mathbf{1 0 b}$ against $\mathrm{CHO}$ cells was relatively good $(13.06 \mu \mathrm{M} \pm 1.4$, as compared to $11 \mu \mathrm{M}$ for cisplatin in $\mathrm{CHO}$ cell lines). ${ }^{64,65}$ The large difference between the activities of the chloride complex 6 and azide complex 10b against $\mathrm{CHO}$ cells (Table 2 ) suggests that otherwise small changes in the coordination sphere of copper can induce dramatic effects in their toxicity against specific cell lines. Importantly, complex 10b presents a degree of selectivity between the studied cell lines (Table 2, entry 2). These results, although preliminary, might help to pave the way for a more general search to prepare tailor-made complexes for specific types of tumours.

\begin{tabular}{|c|c|c|}
\hline Complex & HELA & $\mathrm{CHO}$ \\
\hline 6 & $37.55 \pm 2.35$ & $42.74 \pm 3.99$ \\
\hline $10 \mathrm{~b}$ & $40.05 \pm 2.18$ & $13.06 \pm 1.41$ \\
\hline
\end{tabular}

\section{Conclusions}

Pyca and acepy copper complexes can be easily prepared from inexpensive $\mathrm{Cu}(\mathrm{I})$ and $\mathrm{Cu}(\mathrm{II})$ salts. These complexes promote aldol addition, acetal formation and Schiff condensation under aerobic and mild conditions, thus providing access to new N,Odonor and $\mathrm{N}, \mathrm{N}$ donor multidentate pyridyl ligands and the easy synthesis of copper complexes with nuclearity ranging from monomers to tetramers. The method involves the formation of the ligands in the coordination sphere of the metal, and presents several advantages: i) it facilitates the reaction by activating the electrophile via metal coordination. ii) The formation of the ligand in the coordination sphere of copper might lead to the stabilization of otherwise very reactive species, allowing the preparation of novel ligands. iii) It is a simple and one-pot procedure that simplifies the preparation of the complexes by avoiding the need for previous preparation and purification of the ligand, which is usually time-consuming and can involve several steps. This can be seen in the formation of the tetranuclear $\mathrm{Cu}$ (II) complex 9, which involves an in situ self-aldol reaction and hemiacetal formation. This reaction also illustrates the ability of copper coordination to promote metal enolate formation under mild conditions by increasing the acidity of the $\mathrm{CH}_{3}$ group protons in acepy. This is distinctly different from the case of the pyca ligand, which does not bear acidic protons. The above features make this procedure particularly attractive for transition metal cluster stabilization, since traditional procedures involve the separate synthesis of the appropriate polydentate ligands, which can involve multiple reaction and purification steps, followed by their later addition to the metal precursor.

Deprotonation-protonation of the iminopiridine ligand derived from $\beta$-ala results in a change of the coordination mode from $K^{2}\left(N, N^{\prime}\right)$ in 5 to $K^{3}\left(N, N^{\prime}, O\right)$ in 6 ; this change was demonstrated to be reversible. The chloride ligand in the closed copper complex $\mathbf{6}$ can be easily replaced. The solid-state structures of the resulting complexes vary from monomers to different types of coordination polymers; these structural changes have a definite effect on their magnetic properties. Importantly, the simple substitution of a pseudohalogen for a chloride ligand 
critically changes the cytotoxicity properties of the resulting copper complexes, and can be used to modulate their relaxivities. Among the six Schiff base copper complexes studied, complex $\mathbf{5}$ presented better relaxivity in water and physiological media than similar derivatives with a more rigid scaffold, and phantom images could be obtained. The replacement of a chloride by $\mathrm{N}_{3}$ in particular had a critical impact on cytotoxicity and selectivity of the Schiff base copper(II) complex towards specific cell lines, thus providing a simple strategy to tune the cytotoxic properties of the ligand.

\section{Experimental section}

\section{Materials and general methods.}

Solvents, ligands and other reagents were purchased from commercial suppliers and used without purification unless otherwise stated. Kieselguhr (diatomaceous earth, Merck) was used for filtration. IR spectra in solid were recorded with a Frontier Perkin Elmer Spectrum RX I FT-IR instrument. XRPD measurements (X-Ray Powder Diffraction) were performed in the Laboratory of Instrumental Techniques of the University of Valladolid (L.T.I., www.laboratoriotecnicasinstrumentales.es) using a Bruker Discover D8. The XRPD patterns of all isolated compounds were coincident with those predicted by the software package MERCURY from the X-ray single crystal analysis (see $\mathrm{SI}$ ), thus confirming the identity of the bulk products. Magnetic measurements were performed using a Quantum Design SQUID-VSM magnetometer. Magnetization measurements at different fields at a given temperature confirmed the absence of ferromagnetic impurities. Data were corrected for the sample holder, and their diamagnetism was estimated from the Pascal constants. The static susceptibility measurements were performed in the temperature range 1.8$300 \mathrm{~K}$ with an applied field of $5000 \mathrm{Oe}$. Chinese hamster ovary (CHO) and HELA cells were maintained in Dulbeco's modified Eagle's medium (DMEM) supplemented with $10 \%$ fetal bovine serum, penicillin-streptomycin $(100 \mathrm{U} / \mathrm{ml}$ each) and $2 \mathrm{mM} \mathrm{L}$ glutamine at $37{ }^{\circ} \mathrm{C}$ in a $5 \% \mathrm{CO}_{2}$ humidified atmosphere. Cells were grown as a monolayer to a confluence of up to $80 \%$ in a $35 \mathrm{~mm}$ Petri dish. After trypsinization, the cells were counted with a hemocytometer and seeded at a density of $1.5 \times 10^{4}$ cells per $0.1 \mathrm{ml}$ per well in 96-well microplates prior to cell viability measurements.

Synthesis of complex $\mathbf{1 b}$. To a green solution of $\mathrm{CuCl}_{2} \cdot 2 \mathrm{H}_{2} \mathrm{O}$ $(0.170 \mathrm{~g}, 1 \mathrm{mmol})$ in tetrahydrofuran $(15 \mathrm{~mL})$ was added 2 acetylpyridine $(0.121 \mathrm{~g}, 1 \mathrm{mmol})$ with stirring. After $30 \mathrm{~min}$, a green precipitate appeared. The solid was isolated by filtration with a fritted funnel. Yield $0.238 \mathrm{~g}, 93 \%$. Anal. Calcd. for $\mathrm{C}_{7} \mathrm{H}_{7}$ $\mathrm{Cl}_{2} \mathrm{Cu}_{1} \mathrm{~N}_{1} \mathrm{O}_{1}$ : C 32.90, H 2.76, N 5.48. Found C 32.70, H 2.55, N 5.41. A crystal suitable for $\mathrm{X}$-ray determination was obtained by slow evaporation of a solution of $\mathrm{CuCl}_{2} \cdot 2 \mathrm{H}_{2} \mathrm{O}$ with acepy in $\mathrm{MeOH} / \mathrm{ether}$

Synthesis of complex $\mathbf{2 b}$. a) To a solution of $\mathbf{1 b}$ in methanol $(0.128 \mathrm{~g}, 0.5 \mathrm{mmol})$ was added acepy $(0.061 \mathrm{~g}, 0.5$ $\mathrm{mmol}$ ) with stirring. After $30 \mathrm{~min}$, a dark green precipitate appeared which was collected by filtration in a fritted funnel. b) To a green solution of $\mathrm{CuCl}_{2} \cdot 2 \mathrm{H}_{2} \mathrm{O}(0.170 \mathrm{~g}, 1 \mathrm{mmol})$ in methanol $(15 \mathrm{~mL})$ was added 2-acetylpyridine $(0.242 \mathrm{~g}, 2$ mmol) with stirring. After $30 \mathrm{~min}$, a dark green precipitate appeared. The solid was isolated by filtration with a fritted funnel. Yield $0.355 \mathrm{~g}$, 94\%. Anal. Calcd. for $\mathrm{C}_{14} \mathrm{H}_{14} \mathrm{Cu}_{2} \mathrm{Cl}_{2} \mathrm{~N}_{2} \mathrm{O}_{2}$ : C 44.64, H 3.75, N 7.44. Found C 44.51, H 3.70, N 7.35. A crystal suitable for $\mathrm{X}$-ray determination was obtained by slow evaporation of a solution of $\mathrm{CuCl}_{2} \cdot 2 \mathrm{H}_{2} \mathrm{O}$ with acepy in $\mathrm{MeOH} / \mathrm{H}_{2} \mathrm{O}$.

Synthesis of complex $\mathbf{4}[\boldsymbol{\beta}$-alaH]. To a green solution of $\mathbf{1 b}$ in methanol $(0.128 \mathrm{~g}, 0.5 \mathrm{mmol})$ was added $\beta$-alanine $(0.045 \mathrm{~g}$, $0.5 \mathrm{mmol})$ with stirring. The solution turned a red-brown colour. After several days, it was possible to obtain a few crystals of the complex $4[\beta$-alaH]

[CuCl $\left(\right.$ py-2-C(H)= $\left.\mathrm{NCH}_{2} \mathrm{CH}_{2} \mathrm{COOH}\right)$ ] (5). To a green solution of $\mathrm{CuCl}_{2} \cdot 2 \mathrm{H}_{2} \mathrm{O}(0.170 \mathrm{~g}, 1 \mathrm{mmol})$ in methanol was added pyridine-2-carboxaldehyde (pyca) $(0.107 \mathrm{~g}, 1 \mathrm{mmol})$ and $\beta$ alanine $(0.089 \mathrm{~g}, 1 \mathrm{mmol})$ with stirring. After $30 \mathrm{~min}$, a bright green precipitate appeared. The solid was isolated by filtration and washed again with methanol. Yield $0.292 \mathrm{~g}, 94 \%$. Anal. Calcd. for $\mathrm{C}_{9} \mathrm{H}_{10} \mathrm{Cl}_{2} \mathrm{Cu}_{1} \mathrm{~N}_{2} \mathrm{O}_{2}$ : C 34.58, H 3.22, N 8.96. Found $\mathrm{C}$ 34.57, $\mathrm{H}$ 3.11, N 8.90. A crystal suitable for X-ray determination was obtained by slow diffusion of $\mathrm{MeOH} / \mathrm{Et}_{2} \mathrm{O}$ into a solution of $\mathbf{5}$ in $\mathrm{H}_{2} \mathrm{O}$.

Synthesis of $\left[\mathrm{CuCl}\left(\mathrm{py}-2-\mathrm{C}(\mathrm{H})=\mathrm{NCH}_{2} \mathrm{CH}_{2} \mathrm{COO}\right)\right]$ (6). a) To a bright green suspension of $\mathbf{5}(0.312 \mathrm{~g}, 1 \mathrm{mmol})$ prepared as described above was added NaOMe $(0.054 \mathrm{~g}, 1 \mathrm{mmol})$ in methanol. After $30 \mathrm{~min}$ of stirring, the solution became dark green and was filtered using Kieselguhr. The solution was concentrated, and the crystalline solid was isolated by precipitation with ether. b) To a solution of $\beta$-alanine $(0.178 \mathrm{~g}$, $2 \mathrm{mmol}$ ) in methanol was added complex 7 ( $1 \mathrm{mmol}, 0.474 \mathrm{~g})$ and the mixture was refluxed with stirring for $30 \mathrm{~min}$ to give a dark green solution of $\mathbf{6}$. After filtration to remove traces of undissolved 7, the solution was evaporated slowly to give green microcrystals of 6 . Yield $0.454 \mathrm{~g}, 82 \%$. Anal. Calcd. for $\mathrm{C}_{9} \mathrm{H}_{9} \mathrm{Cl}_{1} \mathrm{Cu}_{1} \mathrm{~N}_{2} \mathrm{O}_{2}$ : C 39.14, $\mathrm{H} 3.29, \mathrm{~N}$ 10.14. Found C 38.55, $\mathrm{H}$ $3.28, \mathrm{~N}$ 9.78. A crystal suitable for $\mathrm{X}$-ray determination was obtained by slow diffusion of $\mathrm{Et}_{2} \mathrm{O}$ into a solution of 6 in $\mathrm{MeOH}$.

Synthesis of complex $7 .^{46}$ a) To a solution of pyridine-2carboxaldehyde (pyca) $(0.107 \mathrm{~g}, 1 \mathrm{mmol})$ in $\mathrm{MeOH}(10 \mathrm{~mL})$ in a $50 \mathrm{ml}$ wide-neck round bottom flask open to air was added $\mathrm{CuCl}(0.099 \mathrm{~g}, 1 \mathrm{mmol})$. Upon stirring, the solid $\mathrm{CuCl}$ first dissolved to give a pale green solution, and after $30 \mathrm{~min}$, a bright green precipitate of $\mathbf{7}$ was produced. The solid was collected in a frit, washed with $\mathrm{MeOH}$, and dried by suction. Yield 0.225 g, 95\%. Anal. Calcd. for $\mathrm{C}_{14} \mathrm{H}_{16} \mathrm{Cl}_{2} \mathrm{Cu}_{2} \mathrm{~N}_{2} \mathrm{O}_{4}$ : C 35.45, $\mathrm{H}$ 3.40, N 5.91. Found C 34.84, H 3.38, N 5.57. Compound 7 was too insoluble to be recrystallized. A crystal suitable for Xray determination was prepared as follows: solid $\mathrm{CuCl}(0.044 \mathrm{~g}$, $0.5 \mathrm{mmol}$ ) was deposited in the bottom of a vial $(2 \mathrm{~cm}$ diameter, $10 \mathrm{~cm}$ high), and was covered by a layer of $\mathrm{MeOH}(5$ $\mathrm{mL}$ ). A second layer consisting of a solution of pyca (0.053 g, $0.5 \mathrm{mmol})$ in $\mathrm{Et}_{2} \mathrm{O}(5 \mathrm{~mL})$ was deposited on top of the $\mathrm{MeOH}$ layer. The vial was left open to air. After several days of slow 
diffusion, a crop of suitable crystals had grown on the wall of the vial. b) To a green solution of $\mathrm{CuCl}_{2} \cdot 2 \mathrm{H}_{2} \mathrm{O}(0.170 \mathrm{~g}, 1$ $\mathrm{mmol})$, in methanol was added pyca $(0.107 \mathrm{~g}, 1 \mathrm{mmol})$ and NaOMe $(0.192 \mathrm{~g}, 3 \mathrm{mmol})$ with stirring. After $15 \mathrm{~min}$, the expected green precipitate appeared.

The precipitate and the crystals were confirmed to be identical by powder diffraction and IR in solid phase. (See text and Electronic Supplementary Information)

Synthesis of complex 8. To a suspension of $\mathrm{CuCl}(0.099 \mathrm{~g}, 1$ $\mathrm{mmol}$ ) in methanol was added acepy $(0.121 \mathrm{~g}, 1 \mathrm{mmol})$. After 2 hours, a dark green microcrystalline precipitate appeared. The precipitate was filtered with a frit and washed with methanol. Yield 0.225 g (95.7\%). Anal. Calcd. $\mathrm{C}_{30} \mathrm{H}_{32} \mathrm{Cl}_{4} \mathrm{Cu}_{4} \mathrm{~N}_{4} \mathrm{O}_{6}: \mathrm{C} 38.31 \mathrm{H}$ 3.43 N 5.96. Found: $\mathrm{C} 38.42$ H 3.39 N 5.81 .

\section{Synthesis of complex 9.}

To a solution of $6(0.276 \mathrm{~g}, 1 \mathrm{mmol})$ in $\mathrm{MeOH}(15 \mathrm{~mL})$ was added $\operatorname{KSCN}(0.098 \mathrm{~g}, 1 \mathrm{mmol}$ ) and the mixture was stirred for $4 \mathrm{~h}$. After this time, a green precipitate appeared and was collected by filtration. Yield $0.245 \mathrm{~g}, 82 \%$. Anal. Calcd. for $\mathrm{C}_{11} \mathrm{H}_{13} \mathrm{Cu}_{1} \mathrm{~N}_{3} \mathrm{O}_{3} \mathrm{~S}_{1}$ : C 39.93, H 3.96, N 12.70. Found C 39.36, $\mathrm{H}$ 3.16, N 19.09. A crystal suitable for $\mathrm{X}$-ray determination was obtained by slow diffusion of methanol/ $\mathrm{Et}_{2} \mathrm{O}$ into a solution of 9 in $\mathrm{H}_{2} \mathrm{O}$.

\section{Synthesis of complex 10a.}

To a solution of $6(0.276 \mathrm{~g}, 1 \mathrm{mmol})$ in $\mathrm{MeOH}(15 \mathrm{~mL})$ was added $\mathrm{NaN}_{3}(0.065 \mathrm{~g}, 1 \mathrm{mmol})$, and the mixture was stirred for $24 \mathrm{~h}$. The green precipitate was isolated by filtration. XPRD showed that the bulk precipitate consisted of a mixture of polymorphs 10a (ca. 30\%) and 10b (ca. 70\%). Single crystals suitable for X-ray analysis were obtained as follows: a solution of $6(0.276 \mathrm{~g}, 1 \mathrm{mmol})$ in methanol was deposited at the bottom of a vial (2 cm diameter and $10 \mathrm{~cm}$ high) and was carefully covered by another layer consisting of $\mathrm{NaN}_{3}(0.065 \mathrm{~g}$, $1 \mathrm{mmol}$ ) in $\mathrm{MeOH}$. After 24 hours of slow diffusion, green single crystals of 10a and 10b were separated and picked by hand under the microscope.

Synthesis of complex 10b. To a solution of $6(0.276 \mathrm{~g}, 1$ $\mathrm{mmol})$ in $\mathrm{MeOH}(15 \mathrm{~mL})$ was added $\mathrm{NaN}_{3}(0.065 \mathrm{~g}, 1 \mathrm{mmol})$ and the mixture was stirred for $1 \mathrm{~h}$. The green precipitate was isolated by filtration. Yield $0.223 \mathrm{~g}, 79 \%$. Anal. Calcd. for $\mathrm{C}_{9} \mathrm{H}_{9} \mathrm{Cu}_{1} \mathrm{~N}_{5} \mathrm{O}_{2}: \mathrm{C} 38.23, \mathrm{H} 3.21, \mathrm{~N} 24.77$. Found C 38.11, H 2.99, $\mathrm{N}$ 24.29. A crystal suitable for X-ray determination was obtained by slow diffusion of methanol/ $\mathrm{Et}_{2} \mathrm{O}$ into a solution of $10 b$ in $\mathrm{H}_{2} \mathrm{O}$.

Synthesis of $\left[\mathrm{Cu}(\mathrm{NCO})\left(\mathrm{py}-2-\mathrm{C}(\mathrm{H})=\mathrm{NCH}_{2} \mathrm{CH}_{2} \mathrm{COO}\right)\right]$ (11). To a solution of $6(0.276 \mathrm{~g}, 1 \mathrm{mmol})$ in $\mathrm{MeOH}(15 \mathrm{~mL})$ was added NaNCO $(0.065 \mathrm{~g}, 1 \mathrm{mmol})$, and the mixture was stirred for $4 \mathrm{~h}$. The solution became green-bluish, and a precipitate appeared. The precipitate was isolated by filtration. Yield $0.172 \mathrm{~g}, 61 \%$. Anal. Calcd. for $\mathrm{C}_{10} \mathrm{H}_{9} \mathrm{Cu}_{1} \mathrm{~N}_{3} \mathrm{O}_{3}: \mathrm{C} 42.48, \mathrm{H} 3.21, \mathrm{~N}$ 14.86. Found C 42.48, H 3.11, N 14.59. A crystal suitable for X-ray determination was obtained by slow diffusion of methanol/Et $\mathrm{H}_{2} \mathrm{O}$ into a solution of $\mathbf{1 1}$ in $\mathrm{H}_{2} \mathrm{O}$.

X-Ray diffraction study of $1 \mathrm{~b}, 2 \mathrm{~b}, 4[\beta$-alaH], 5, 6, 7, 8, 9, 10a, 10b and 11.
Diffraction data were collected using an Oxford Diffraction Supernova diffractometer equipped with an Atlas CCD area detector and a four-circle kappa goniometer. For data collection, Mo or Cu micro-focus sources with multilayer optics were used. Data integration, scaling and empirical absorption correction were carried out using the CrysAlis Program package. ${ }^{66}$ The structure was solved using direct methods and refined by Full-Matrix-Least-Squares against $\mathrm{F}^{2}$ with SHELX ${ }^{67}$ in OLEX2. ${ }^{68}$ The non-hydrogen atoms were refined anisotropically, and hydrogen atoms were placed at idealised positions and refined using the riding model. Graphics were made with OLEX2 and MERCURY. ${ }^{69}$ Crystal data, particular details and CCDC reference numbers are given in the Supporting Information Table S3.

\section{Conflicts of interest}

There are no conflicts to declare.

\section{Acknowledgements}

We thank the Spanish Ministry of Science, Innovation and Universities (MCIU) for funding (project numbers PGC2018096880-A-I00, MCIU/AEI/FEDER, UE and PGC2018-099470-BI00, MCIU/AEI/FEDER, UE) and Junta de Castilla y León (VA130G18). R.G.-R. acknowledges the Spanish MINECO/AEI and the European Union (ESF) for a Ramon y Cajal contract (RYC-2015-19035).

\section{Notes and references}

1 C. Santini, M. Pellei, V. Gandin, M. Porchia, F. Tisato and C. Marzano, Chem. Rev., 2014, 114, 815-862.

2 E. L. Que, E. Gianolio, S. L. Baker, A. P. Wong, S. Aime and C. J. Chang, J. Am. Chem. Soc., 2009, 131, 8527-8536.

3 C. J. Anderson and R. Ferdani, Cancer Biother. Radio., 2009, 24, 379-393.

4 F. Wang, P. Jiao, M. Qi, M. Frezza, Q. P. Dou and B. Yan, Curr. Med. Chem., 2010, 17, 2685-2698.

5 A. Cruces-Sande, E. Méndez-Álvarez and R. Soto-Otero, J. Neurochem., 2017, 141, 738-749.

6 E. Nyvltova, A. Barrientos and J. Hosler, in Encyclopedia of Inorganic and Bioinorganic Chemistry, John Wiley \& Sons, Ltd, 2011.

7 D. J. Kosman, in Encyclopedia of Inorganic and Bioinorganic Chemistry, John Wiley \& Sons, Ltd, 2011.

8 S. Li, L. Wang, F. Yu, Z. Zhu, D. Shobaki, H. Chen, M. Wang, J. Wang, G. Qin, U. J. Erasquin, L. Ren, Y. Wang and C. Cai, Chem. Sci., 2017, 8, 2107-2114.

9 X.-Y. Qin, Y.-N. Wang, X.-P. Yang, J.-J. Liang, J.-L. Liu and Z.-H. Luo, Dalton Trans., 2017, 46, 16446-16454.

10 K. C. Park, L. Fouani, P. J. Jansson, D. Wooi, S. Sahni, D. J. R. Lane, D. Palanimuthu, H. C. Lok, Z. Kovacevic, M. L. H. Huang, D. S. Kalinowski and D. R. Richardson, Metallomics, 2016, 8, 874-886.

11 D. B. Lovejoy, P. J. Jansson, U. T. Brunk, J. Wong, P. Ponka and D. R. Richardson, Cancer Res., 2011, 71, 5871-5880.

12 M. A. Malik, O. A. Dar, P. Gull, M. Y. Wani and A. A. Hashmi, MedChemComm, 2018, 9, 409-436. 
13 S. Adhikari, S. Lohar, B. Kumari, A. Banerjee, R. Bandopadhyay, J. S. Matalobos and D. Das, New J. Chem. 2016, 40, 10094-10099.

14 P. U. Maheswari, S. Roy, H. den Dulk, S. Barends, G. van Wezel, B. Kozlevčar, P. Gamez and J. Reedijk, J. Am. Chem. Soc., 2006, 128, 710-711.

15 P. U. Maheswari, M. v. d. Ster, S. Smulders, S. Barends, G. P. v. Wezel, C. Massera, S. Roy, H. d. Dulk, P. Gamez and J. Reedijk, Inorg. Chem., 2008, 47, 3719-3727.

16 X. Qiao, Z.-Y. Ma, C.-Z. Xie, F. Xue, Y.-W. Zhang, J.-Y. Xu, Z.-Y. Qiang, J.-S. Lou, G.-J. Chen and S.-P. Yan, J. Inorg. Biochem., 2011, 105, 728-737.

17 D.-D. Li, J.-L. Tian, W. Gu, X. Liu, H.-H. Zeng and S.-P. Yan, J. Inorg. Biochem., 2011, 105, 894-901.

18 Z.-Y. Ma, X. Qiao, C.-Z. Xie, J. Shao, J.-Y. Xu, Z.-Y. Qiang and J.S. Lou, J. Inorg. Biochem., 2012, 117, 1-9.

19 S. Sinharay and M. D. Pagel, Annu. Rev. Anal. Chem. (Palo Alto Calif.), 2016, 9, 95-115.

20 A. Neuwelt, N. Sidhu, C.-A. A. Hu, G. Mlady, S. C. Eberhardt and L. O. Sillerud, Am. J. Roentgenol., 2015, 204, W302W313.

21 a) D. V. Hingorani, A. S. Bernstein and M. D. Pagel, Contrast Media Mol. Imaging, 2015, 10, 245-265. b) A. Datta and K. N. Raymond, Acc Chem Res, 2009, 42, 938-947. c) E. J. Werner, A. Datta, C. J. Jocher and K. N. Raymond, Angew. Chem., Int Ed. 47, 8568-8580. d) P. Caravan, J. J. Ellison, T. J. McMurry and R. B. Lauffer, Chem. Rev, 1999, 99, 2293-2352. e) P. Caravan, Chem. Soc. Rev, 2006, 35, 512-523.

22 E. Kanal and M. F. Tweedle, Radiology, 2015, 275, 630-634.

23 J. Ramalho, R. C. Semelka, M. Ramalho, R. H. Nunes, M. AlObaidy and M. Castillo, Am. J. Neuroradiol., 2016, 37, 1192-1198.

24 K. Du, E. A. Waters and T. D. Harris, Chem. Sci., 2017, 8 4424-4430.

25 P. J. Burns, J. M. Cox and J. R. Morrow, Inorg. Chem., 2017, 56, 4545-4554.

26 P. B. Tsitovich, J. M. Cox, J. A. Spernyak and J. R. Morrow, Inorg. Chem., 2016, 55, 12001-12010.

27 K. Du and T. D. Harris, J. Am. Chem. Soc., 2016, 138, 78047807.

28 M. L. Blackwell, C. T. Farrar, B. Fischl and B. R. Rosen, Neuroimage, 2009, 46, 382-393.

29 C. M. Alvarez, R. Garcia-Rodriguez and D. Miguel, Dalton Trans., 2007, 3546-3554.

30 C. M. Alvarez, R. Carrillo, R. Garcia-Rodriguez and D. Miguel, Chem. Commun., 2012, 48, 7705-7707.

31 C. M. Alvarez, L. A. Garcia-Escudero, R. Garcia-Rodriguez and D. Miguel, Chem. Commun., 2012, 48, 7209-7211.

32 C. M. Álvarez, R. García-Rodríguez, J. M. Martín-Alvarez, D. Miguel and J. A. Turiel, Inorg. Chem., 2012, 51, 3938-3940.

33 C. M. Álvarez, R. Carrillo, R. García-Rodríguez and D. Miguel, Chem. Eur. J., 2013, 19, 8285-8293.

34 C. M. Álvarez, R. García-Rodríguez and D. Miguel, Dalton Trans., 2016, 45, 963-972.

35 C. M. Alvarez, R. Garcia-Rodriguez, J. M. Martin-Alvarez and D. Miguel, Dalton Trans., 2010, 39, 1201-1203.

36 C. M. Alvarez, R. Garcia-Rodriguez and D. Miguel, J. Organomet. Chem., 2007, 692, 5717-5726.

37 L. Álvarez-Miguel, H. Barbero, A. Sacristán-Martín, J. M. Martín Álvarez, A. Pérez-Encabo, C. M. Álvarez, R. GarcíaRodríguez and D. Miguel, Inorg. Chem., 2018, 57, 264-276.

38 E. Colacio, M. Ghazi, R. Kivekäs and J. M. Moreno, Inorg. Chem., 2000, 39, 2882-2890.

39 E. Colacio, J. M. Domínguez-Vera, M. Ghazi, R. Kivekäs, M. Klinga and J. M. Moreno, Eur. J. Inorg. Chem., 1999, 441-445.

40 J. Vančo, J. Marek, Z. Trávníček, E. Račanská, J. Muselík and O. g. Švajlenová, J. Inorg. Biochem., 2008, 102, 595-605.
41 S. Hazra, A. P. C. Ribeiro, M. F. C. Guedes da Silva, C. A. Nieto de Castro and A. J. L. Pombeiro, Dalton Trans., 2016, 45, 13957-13968.

42 A. P. C. Ribeiro, L. M. D. R. S. Martins, S. Hazra and A. J. L. Pombeiro, Comptes Rendus Chimie, 2015, 18, 758-765.

43 S. Hazra, S. Mukherjee, M. F. C. Guedes da Silva and A. J. L. Pombeiro, RSC Adv., 2014, 4, 48449-48457.

44 S. Hazra, A. Karmakar, M. d. F. C. Guedes da Silva, L. u. Dlhan, R. Boca and A. J. L. Pombeiro, New J. Chem., 2015, 39, 34243434.

45 A. W. Addison, T. N. Rao, J. Reedijk, J. van Rijn and G. C. Verschoor, J. Chem. Soc., Dalton Trans., 1984, 1349-1356.

46 S. Boonlue, A. Sirikulkajorn and K. Chainok, Acta Cryst. E, 2015, 71, m44-m45.

47 M. D. Soutullo, R. A. O'Brien, K. E. Gaines and J. H. Davis, Chem. Commun., 2009, 2529-2531.

48 J. Clayden, N. Greeves and S. Warren, Organic Chemistry, OUP Oxford, 2012

49 S. Barman, K. L. Diehl and E. V. Anslyn, RSC Adv., 2014, 4, 28893-28900.

50 L. You and E. V. Anslyn, Org. Lett., 2009, 11, 5126-5129.

51 A. Solchinger, K. Wurst, H. Kopacka and B. Bildstein, Cryst. Growth Des., 2007, 7, 2380-2381.

52 B. Buchs, W. Fieber, D. Drahoňovský, J.-M. Lehn and A. Herrmann, Chem. Biodivers., 2012, 9, 689-701.

53 D. Drahoňovský and J.-M. Lehn, The Journal of Organic Chemistry, 2009, 74, 8428-8432.

54 A. A. Kitos, C. G. Efthymiou, M. J. Manos, A. J. Tasiopoulos, V. Nastopoulos, A. Escuer and S. P. Perlepes, Dalton Trans. 2016, 45, 1063-1077.

55 K. C. Mondal, O. Sengupta and P. S. Mukherjee, Inorg. Chem. Commun., 2009, 12, 682-685.

56 M. G. B. Drew, J. P. Naskar, S. Chowdhury and D. Datta, Eur J. Inorg. Chem., 2005, 4834-4839.

57 R. L. Carlin, Magnetochemistry, Springer-Verlag Berlin, 1986.

58 J. Suarez-Varela, J. M. Dominguez-Vera, E. Colacio, J. C. AvilaRoson, M. A. Hidalgo and D. Martin-Ramos, J. Chem. Soc. Dalton Trans., 1995, 2143-2146.

59 G. Ferrauto, S. Aime, M. T. McMahon, J. R. Morrow, E. M. Snyder, A. Li and R. Bartha, in Contrast Agents for MRI: Experimental Methods, The Royal Society of Chemistry, 2018, pp. 243-317.

60 M. T. McMahon, A. A. Gilad, J. W. M. Bulte and P. C. M. van Zijl, Chemical Exchange Saturation Transfer Imaging: Advances and Applications, Pan Stanford Publishing, 2017.

61 L. Dunbar, R. J. Sowden, K. D. Trotter, M. K. Taylor, D. Smith, A. R. Kennedy, J. Reglinski and C. M. Spickett, Biometals, 2015, 28, 903-912.

62 D.-W. Zhang, Z.-Y. Yang, S.-P. Zhang and R.-D. Yang, Transition Met. Chem., 2006, 31, 333-336.

63 R. B. Lauffer, Chem. Rev., 1987, 87, 901-927.

64 E. Guney, V. T. Yilmaz, F. Ari, O. Buyukgungor and E. Ulukaya, Polyhedron, 2011, 30, 114-122.

65 T. Lazarevic, A. Rilak and Z. D. Bugarcic, Eur. J. Med. Chem., 2017, 142, 8-31.

66 v. CrysAlisPro-Data Collection and Integration Software, Agilent Technologies UK Ltd., Oxford, UK, 2011.

67 G. Sheldrick, Acta Cryst. A, 2008, 64, 112-122.

68 O. V. Dolomanov, L. J. Bourhis, R. J. Gildea, J. A. K. Howard and H. Puschmann, J. Appl. Crystallogr., 2009, 42, 339-341.

69 C. F. Macrae, I. J. Bruno, J. A. Chisholm, P. R. Edgington, P. McCabe, E. Pidcock, L. Rodriguez-Monge, R. Taylor, J. van de Streek and P. A. Wood, J. Appl. Crystallogr., 2008, 41, 466470. 


\section{ARTICLE}

Copper complexes for the promotion of iminopyridine ligands derived from $\beta$ alanine and self-aldol additons: Magnetic behaviour, relaxivity and cytotoxic properties.

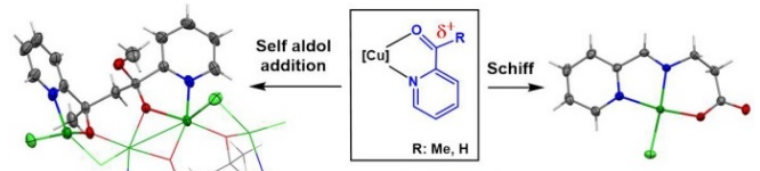

Cytotoxicity

L. Álvarez-Miguel, I. Álvarez-Miguel, J.

The template effect in $\mathrm{K}^{2}$ $(\mathrm{N}, \mathrm{O}) \quad$ chelated $\mathrm{Cu}(\mathrm{II})$ complexes can promote $\mathrm{C}-\mathrm{C}$ or $\mathrm{C}-\mathrm{N}$ coupling products.

M. Martín-Álvarez, C. M. Álvarez, G.

Rogez, R. García-Rodríguez and D. Miguel. 